\title{
Understanding and Informing the Policy Environment: State-Level Renewable Fuels Standards
}

Technical Report NREL/TP-640-41075 January 2007

E. Brown, K. Cory, and D. Arent

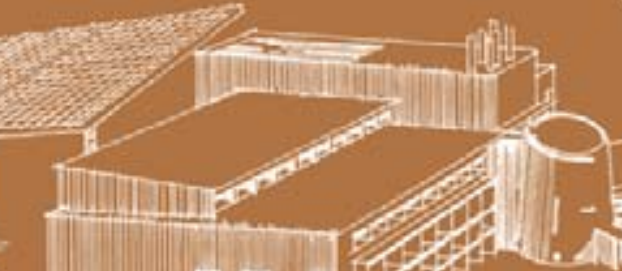




\section{Understanding and Informing the Policy Environment: State-Level Renewable Fuels Standards}

Technical Report NREL/TP-640-41075 January 2007

E. Brown, K. Cory, and D. Arent

Prepared under Task No(s). IGST.6500 and 6001.5010

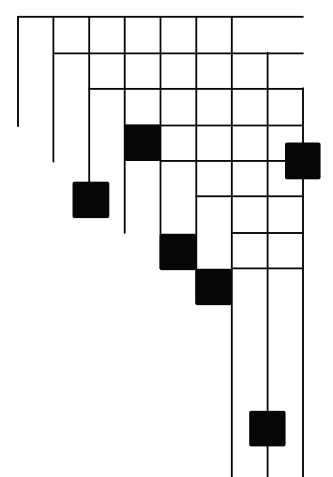

National Renewable Energy Laboratory

1617 Cole Boulevard, Golden, Colorado 80401-3393

303-275-3000 • www.nrel.gov

Operated for the U.S. Department of Energy

Office of Energy Efficiency and Renewable Energy

by Midwest Research Institute - Battelle

Contract No. DE-AC36-99-G010337 


\section{NOTICE}

This report was prepared as an account of work sponsored by an agency of the United States government. Neither the United States government nor any agency thereof, nor any of their employees, makes any warranty, express or implied, or assumes any legal liability or responsibility for the accuracy, completeness, or usefulness of any information, apparatus, product, or process disclosed, or represents that its use would not infringe privately owned rights. Reference herein to any specific commercial product, process, or service by trade name, trademark, manufacturer, or otherwise does not necessarily constitute or imply its endorsement, recommendation, or favoring by the United States government or any agency thereof. The views and opinions of authors expressed herein do not necessarily state or reflect those of the United States government or any agency thereof.

Available electronically at http://www.osti.gov/bridge

Available for a processing fee to U.S. Department of Energy and its contractors, in paper, from:

U.S. Department of Energy

Office of Scientific and Technical Information

P.O. Box 62

Oak Ridge, TN 37831-0062

phone: 865.576 .8401

fax: 865.576 .5728

email: mailto:reports@adonis.osti.gov

Available for sale to the public, in paper, from:

U.S. Department of Commerce

National Technical Information Service

5285 Port Royal Road

Springfield, VA 22161

phone: 800.553.6847

fax: 703.605.6900

email: orders@ntis.fedworld.gov

online ordering: http://www.ntis.gov/ordering.htm 


\section{Table of Contents}

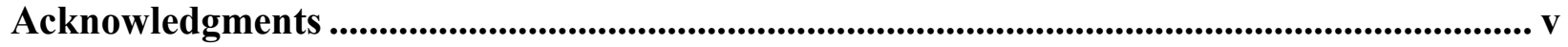

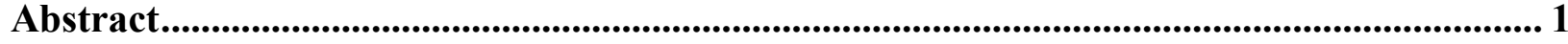

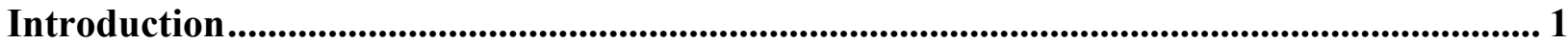

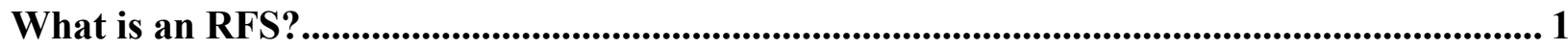

Status of State-Level RFS in the United States ...................................................................... 2

Trends in State-Level Policy Development .............................................................................. 6

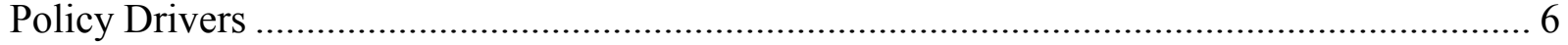

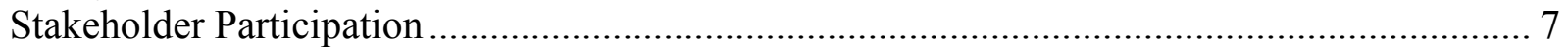

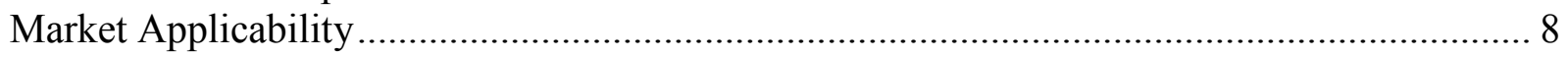

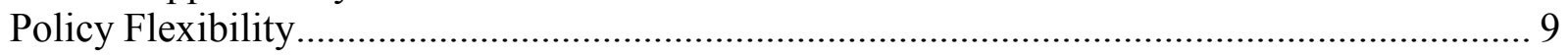

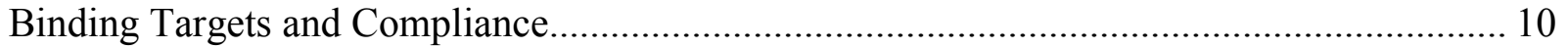

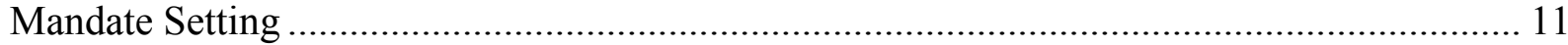

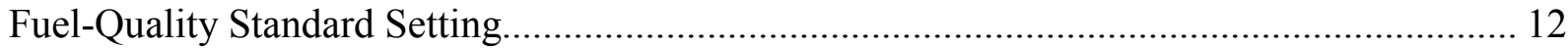

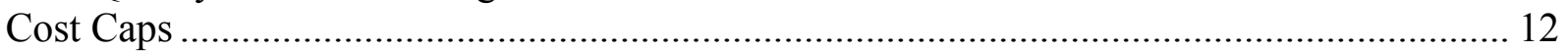

Summary of Current State Policy Trends ................................................................................... 13

Lessons to Inform State Policy: National and International RFS Policies ............................. 13

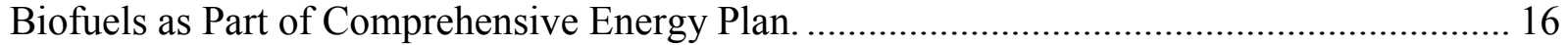

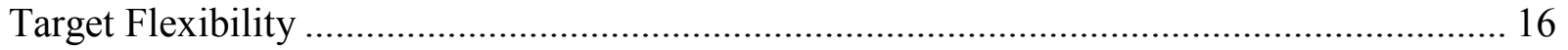

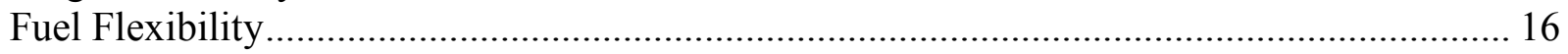

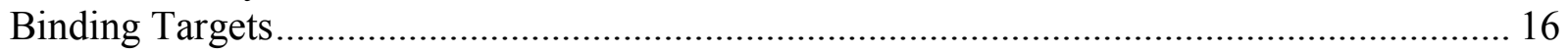

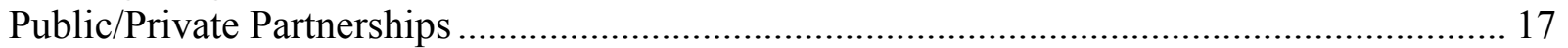

Summary of National and International RFS Lessons................................................... 17

Lessons to Inform State Policy: Internationals and State Renewable Portfolio Standards

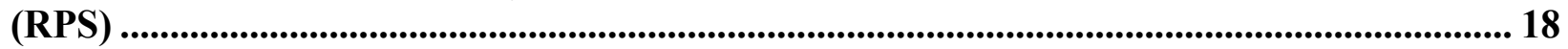

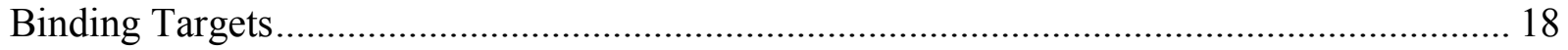

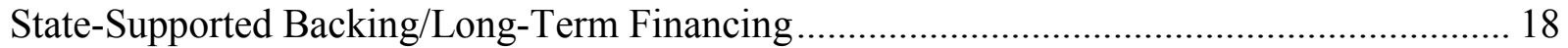

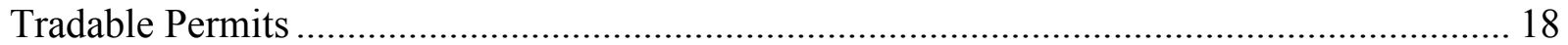

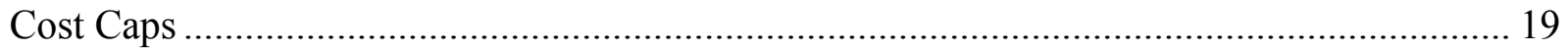

Interaction with Other Policies/Programs ................................................................... 19

Summary of Lessons from International and State RPS ................................................ 20

Conclusion: Informing Current and Future State RFS Policies ............................................ 20

Appendix: U.S. States with RFS Policy Action (December 2006) ........................................... 22

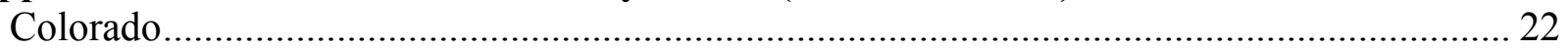

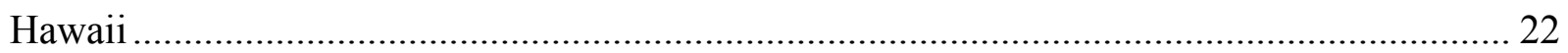

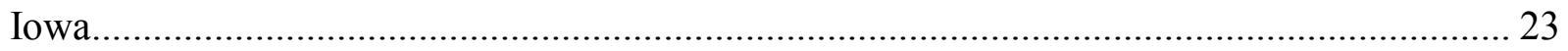

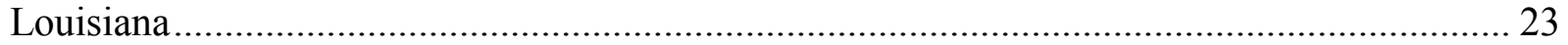

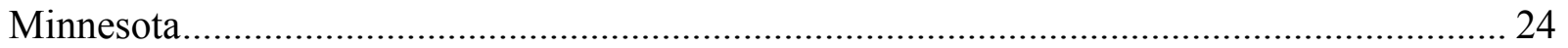

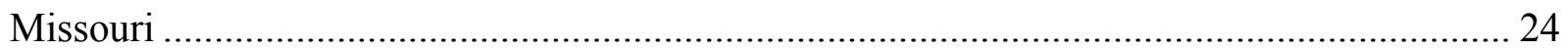

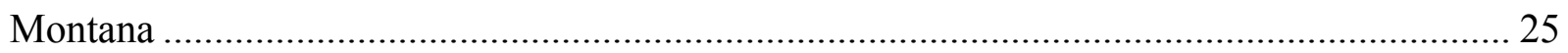

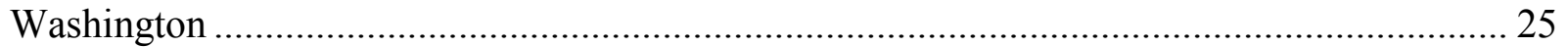

Summary of Proposed RFS Policies (December 2006) ................................................... 25

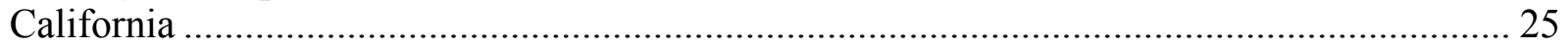

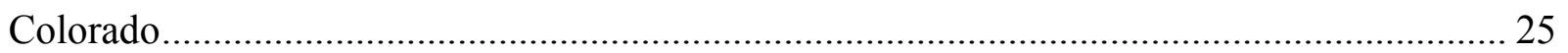




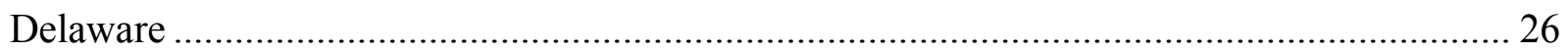

Georgia - State Vehicle Requirement...................................................................... 26

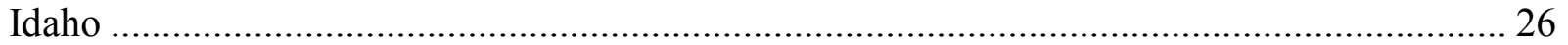

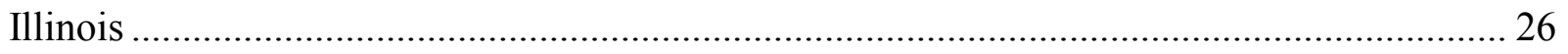

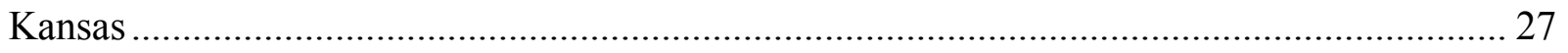

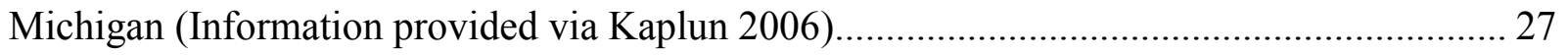

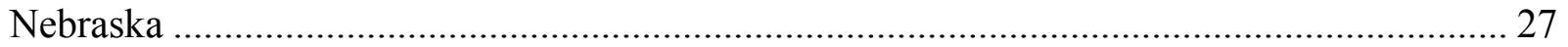

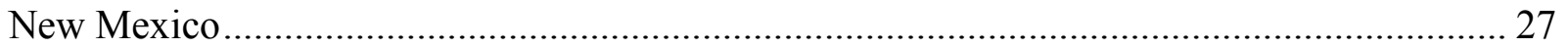

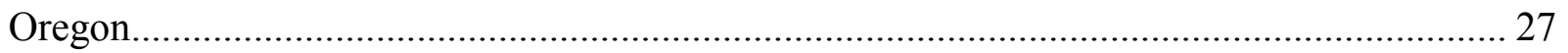

Tennessee - State Vehicle Requirement .................................................................. 28

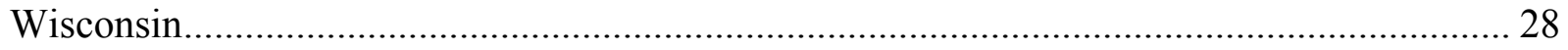

Summary of Other State RFS Activity (December 2006) ................................................ 28

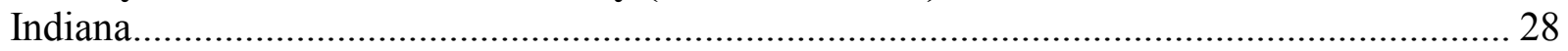

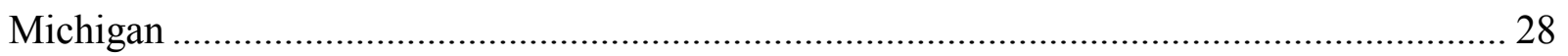

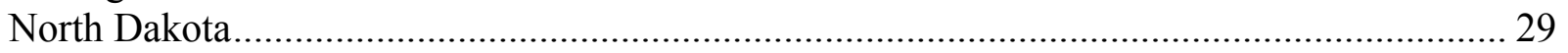

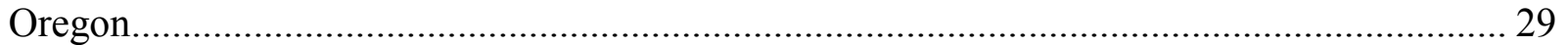

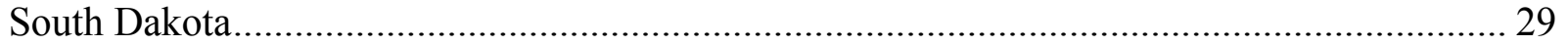

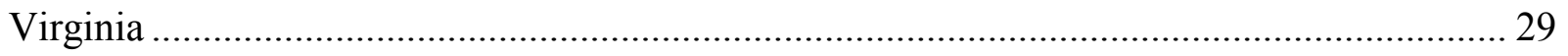




\section{Acknowledgments}

This report is made possible by the many contributions of state policymakers and legislative assistants, who pulled together information and dusted off dead legislation for the authors, as well as the NREL librarians, who also assisted in gathering data. Data was also gathered and critical input provided by Samantha Slater and Julia Davies (Renewable Fuels Association). An indispensable resource throughout the development of this paper, although not specifically cited in any one place, is the Alternative Fuels Data Center (http://www.eere.energy.gov/afdc/), which tracks alternative fuels technologies and the policies that surround them. The authors would also like to thank Jerry Kotas and Dan Beckley (Department of Energy - DOE); John Brown, Ron Benioff, David Hurlbut, John Sheehan, Robert Wallace, Victoria Putsche, and Roya Stanley (NREL); Rebecca White (U.S. Environmental Protection Agency - EPA); Russ Hendricks (Idaho Farm Bureau Federation); and Josh Zahn (National Biodiesel Board), for their thoughtful review of drafts of this report. This report would not have been possible without support from Dan Beckley and Jerry Kotas at DOE, as well as Bobi Garrett at NREL. Our thanks also go to Michelle Kubik for her editing support. 


\begin{abstract}
Renewable fuels standard (RFS) policies are becoming a popular public policy mechanism for developing the market for renewable fuels in the transportation sector. During the past decade, U.S. states and several countries began implementing these more market-based (less command and control) policies to support increased biofuels production and use. This paper presents an overview of current and proposed U.S. state-level policies, as well as selected electric sector policies and international fuel standard policies. Current U.S. state-level renewable fuel policies list drivers including an improved economy and environment, as well as fuel self-sufficiency. Best practices and experience from an evaluation of renewable portfolio standards (RPS) in the United States and international RFS policies can inform U.S. state-level policy by illustrating the importance of policy flexibility, binding targets, effective cost caps, and tradable permits. Understanding and building on the experiences from these previous policies can improve the policy mechanism and further develop a market for renewable fuels to meet the goals of improved economy, environment, and fuel self-sufficiency.
\end{abstract}

\title{
Introduction
}

While there are many policy mechanisms for promoting growth in renewable energy markets (e.g., prescriptive fuel-type mechanisms, tariffs, straight financial incentives), renewable fuels standard (RFS) policies are becoming the prevalent public policy mechanism for developing the market for renewable fuels in the transportation sector. This market-based policy mechanism, when ideally designed and executed, provides opportunity for the development of renewable fuels markets through the correction of market failures by empowering the market actors to develop least-cost solutions for fulfilling the mandate. Market failures specific to renewable fuels markets include embedded fossil fuel infrastructure and culture, increased risk in renewable fuel development, consumer information gaps, and lack of quantification of non-economic benefits of renewable energy. RFS policies are an increasingly popular mechanism for addressing these failures in the United States and around the world.

Prior to 2006, two U.S. states and several countries implemented these market-based policies. In 2006, the U.S. federal government began implementation of a national-level RFS, and eight more states enacted RFS policies to promote economic growth, reduce dependence on foreign oil, and reduce the transportation sector impact on the environment. Seventeen more states have recently considered legislation. The increase in renewable fuel policy activity captures the interest in promoting renewable fuels, but also allows for constructive comparison of approaches and possible impacts for the state, nation, and industry. This review presents summaries of select national-scale RFS policies (including the United States), as well as international and state renewable portfolio standard policies (in the electric sector), which are provided to inform current and developing state-level RFS policy debate. This analysis offers comparative information to help inform policy development of a competitive, economically efficient renewable fuels market.

\section{What is an RFS?}

Renewable fuels standard (RFS) policies require that a certain percentage of transportation fuel provided to a given geographic area is replaced by renewable fuels. Implementation of the requirement has been based on volume or total fuel sales, and may be further targeted toward the replacement of gasoline or diesel fuels, or even to specific grades of gasoline. The mechanism 
may be applicable to a variety of locations along the supply chain (e.g., refiners, blenders, importers, distributors, and/or retail sellers). Depending on how it is enacted, the flexibility of the policy mechanism could allow for developing least-cost solutions for renewable fuel markets while promoting continued innovation in the development of cost-effective renewable fuels.

The term "renewable fuels standard" originates from a similar policy mechanism used to develop the market for renewable energy use in the electric sector. These policies, called renewable portfolio standards (RPS), are now in place in $23^{1}$ states and the District of Columbia. Evaluation of the RPS programs show that the policies have resulted in at least 4,000 MW of increased renewable electricity capacity at the state level (UCS 2006a, EIA AEO 2006). Lessons learned from extensive analysis of and research on RPS policies is discussed in a later section of the paper.

\section{Status of State-Level RFS in the U.S.}

Figure 1 illustrates the geographic distribution of states "with" and those "considering" policies. Ten states have RFS policies in place, as shown in Table 1. At least another 17 states are examining or are considering implementing their own RFS policies, shown in Table 2 and detailed in the Appendix. ${ }^{2}$ The number of states considering this mechanism indicates that critical review is needed to ensure that the policies developed meet the goals of state legislation. Table 3 summarizes policies in place by state, goal, and date of expected compliance. The following sections describe the trends in drivers and policy development approaches for the states with active policies. The Appendix lists policy details for these in-place policies, as well as those proposed in recent state legislative sessions.

\footnotetext{
${ }^{1}$ Includes states with voluntary RPS-type policies

${ }^{2}$ The list of states considering RFS or RFS-type policies is based on best available information, but may be missing some states where little or no published information regarding consideration is accessible. Further, this review focuses on legislative policies and does not include an extensive review of gubernatorial executive orders.
} 


\begin{tabular}{|c|c|}
\hline State & Status \\
\hline Colorado* & Enacted 2006 \\
\hline Hawaii & $\begin{array}{l}\text { Enacted 1994, } \\
\text { Revised 2004, } 2006\end{array}$ \\
\hline lowa & Enacted 2006 \\
\hline Louisiana & Enacted 2006 \\
\hline Maryland* & Enacted 2006 \\
\hline Minnesota & $\begin{array}{l}\text { Enacted 1991, } \\
\text { Revised } 2006\end{array}$ \\
\hline Missouri & Enacted 2006 \\
\hline Montana & Enacted 2006 \\
\hline Washington & Enacted 2006 \\
\hline Ohio* & Enacted 2006 \\
\hline \multicolumn{2}{|c|}{ * indicates state vehicle fuel use only polic } \\
\hline
\end{tabular}

\begin{tabular}{|l|l|}
\hline \multicolumn{2}{|l|}{$\begin{array}{l}\text { Table 2. Summary of States Considering } \\
\text { RFS (as of December 2006) }\end{array}$} \\
\hline State & Status \\
\hline California & Proposed \\
\hline Colorado & Proposed \\
\hline Delaware & Proposed \\
\hline Georgia* & Proposed \\
\hline Idaho & Proposed \\
\hline Illinois & Proposed \\
\hline Indiana & Interest \\
\hline Kansas & Proposed \\
\hline Michigan & Proposed, further interest \\
\hline Nebraska & Proposed \\
\hline New Mexico & Proposed \\
\hline North Dakota & Interest \\
\hline Oregon & Proposed, further interest \\
\hline South Dakota & Interest \\
\hline Tennessee* & Proposed \\
\hline Virginia & Interest \\
\hline Wisconsin & Proposed \\
\hline${ }^{*}$ indicates state vehicle fuel use only policy \\
\hline
\end{tabular}



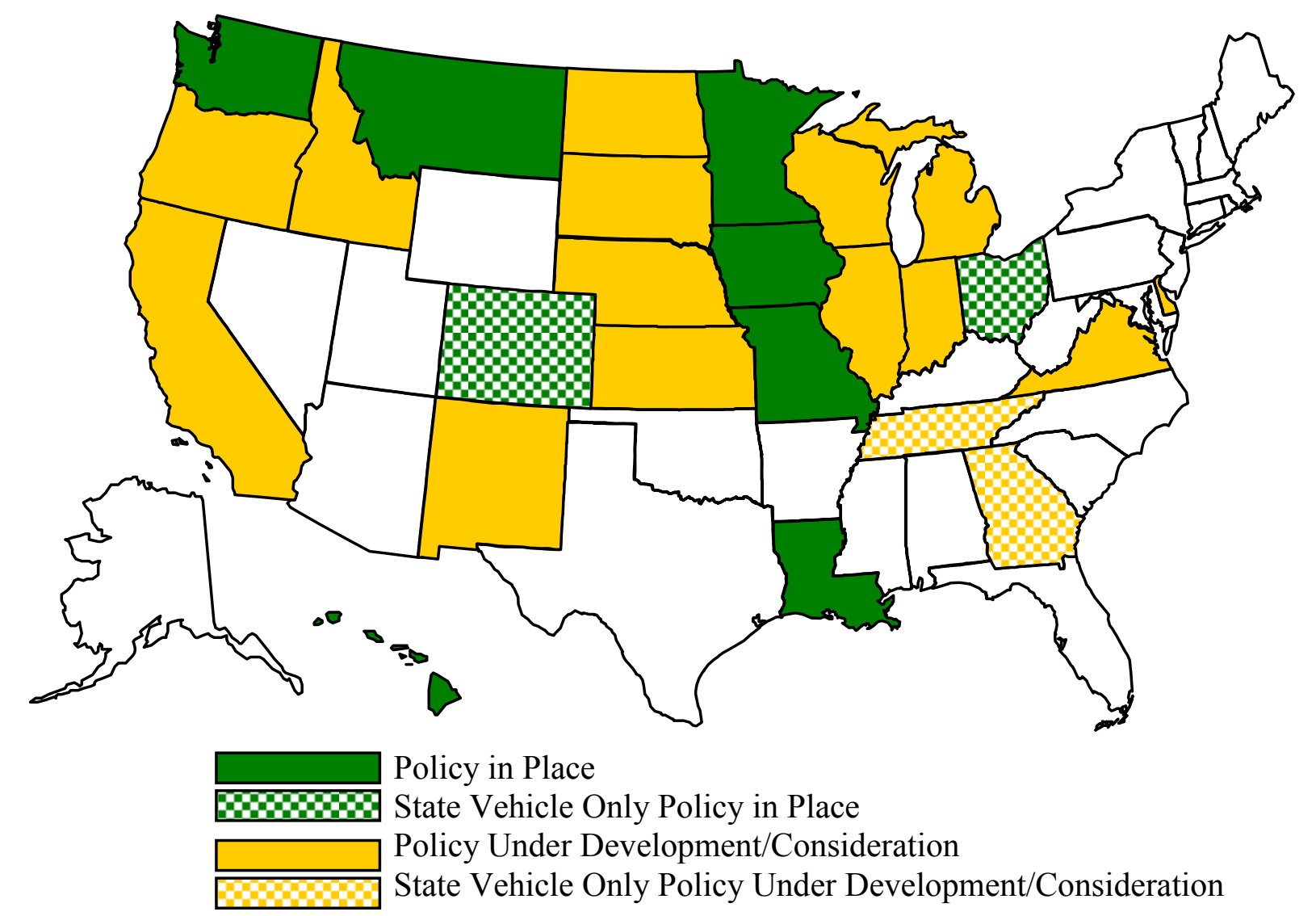

Figure 1. Map of U.S. States "With" and "Considering" RFS Policies (December 2006) 


\begin{tabular}{|c|c|c|}
\hline State & Requirement & Date of Compliance \\
\hline Colorado & $\begin{array}{l}\text { All state-owned diesel vehicles and equipment to be fueled with B20. Policy is negated if the } \\
\text { blend of } 20 \% \text { biodiesel/ } 80 \% \text { diesel by volume (B20) is } \$ 0.10 \text { more per gallon than the price of } \\
\text { conventional diesel. }\end{array}$ & 2007 \\
\hline Hawaii & At least $85 \%$ of gasoline sold must contain $10 \%$ ethanol by volume (E10). & 2008 \\
\hline lowa & $\begin{array}{l}\text { Equivalent of } 25 \% \text { of all gasoline sales must come from renewable sources [either } 10 \% \text { or } \\
85 \% \text { ethanol blends (E10, E85), or biofuel that is } 1 \% \text { biodiesel by volume (B1) at a minimum]. }\end{array}$ & 2020 \\
\hline Louisiana & $\begin{array}{l}\text { Total motor gasoline sales must contain } 2 \% \text { ethanol by volume (E2). } \\
\text { Total diesel sales must contain } 2 \% \text { biodiesel by volume (B2). }\end{array}$ & $\begin{array}{l}2015 \text { or } 6 \text { months after in-state } \\
\text { production reaches } 50 \mathrm{mgy}^{*} \\
\text { ethanol and } 10 \mathrm{mgy} \text { biodiesel }\end{array}$ \\
\hline Maryland & Half the state fleet normally powered by diesel must be using a blend of at least B5. & 2008 \\
\hline Minnesota & $\begin{array}{l}\text { Total motor gasoline sales must contain } 20 \% \text { ethanol by volume (E20). } \\
\text { Total diesel sales must contain } 2 \% \text { biodiesel by volume (B2). }\end{array}$ & 2013 \\
\hline Missouri & Total non-premium motor gasoline sales must contain $10 \%$ ethanol by volume (E10). & 2008 \\
\hline Montana & Total non-premium motor gasoline sales must contain $10 \%$ ethanol by volume (E10). & $\begin{array}{l}3 \text { months after in-state } \\
\text { production of ethanol reaches } 40 \\
\text { mgy }\end{array}$ \\
\hline Ohio & $\begin{array}{l}\text { For state vehicles owned or leased, shall use at least } 60,000 \text { gallons of E85 per year by } \\
\text { January } 1,2007 \text {, with an increase of } 5,000 \text { gallons per year after that; and at least } 1 \text { million } \\
\text { gallons of biodiesel per year by January } 1,2007 \text {, with an increase of } 100,000 \text { gallons per year } \\
\text { each year. }\end{array}$ & 2007 and beyond \\
\hline Washington & $\begin{array}{l}\text { Total motor gasoline sales must contain } 2 \% \text { ethanol by volume (E2). } \\
\text { Equivalent of } 2 \% \text { of diesel sales must be biodiesel. }\end{array}$ & 2008 \\
\hline
\end{tabular}




\section{Trends in State-Level Policy Development}

Renewable fuel policy is still in the early stages of development. However, as more policies have been enacted, several policy trends have emerged. There is a general uniformity in the legislatively stated drivers behind enacting such policies, but states have developed different approaches to policy development, including the variety of stakeholders included in planning, the definition of the market to which the mandate applies, specific renewable fuel type requirements, binding targets and enforcement provisions, the actual standards set by the mandate (in terms of the amount of renewable fuel), the potential impacts of meeting the policy's goals, and triggers for when the requirement will begin, based on supply development.

\section{Policy Drivers}

There are five primary drivers cited in legislation as the motivations for RFS creation. Table 4 summarizes these primary drivers for the RFS policies in place, as of the end of 2006. ${ }^{3}$ All states indicated the basis for the law was to build a renewable fuels market. One driver is the expected positive impact on the rural economy through creating a new market for rural products. Both Louisiana and Washington listed energy security or energy independence as a driver (Louisiana 2006, Washington 2006). With increasing volatility in fossil fuel prices and increased global uncertainty associated with them, reduction of dependence on foreign oil and increasing the use of locally produced fuels are increasingly driving RFS policies. Finally, both Louisiana and Washington list environmental benefits such as improved constituency health and air quality as policy drivers.

\begin{tabular}{|c|c|c|c|c|}
\hline \multicolumn{5}{|c|}{$\begin{array}{l}\text { Table 4. Primary Drivers (as Noted in Legislation) for State Renewable Fuels } \\
\text { Standard Development (Enacted Policies, as of December 2006) } \\
\text { State } \\
\text { Stated Drivers }\end{array}$} \\
\hline & \multirow{2}{*}{$\begin{array}{l}\text { Improve } \\
\text { Rural } \\
\text { Economy }\end{array}$} & \multirow{2}{*}{$\begin{array}{l}\text { Increase use of } \\
\text { domestic fuels }\end{array}$} & \multicolumn{2}{|c|}{ Environmental } \\
\hline & & & $\begin{array}{l}\text { Improved } \\
\text { Health }\end{array}$ & Air Quality \\
\hline Hawaii & & $\mathrm{X}$ & & \\
\hline lowa & $\mathrm{X}$ & $X$ & & \\
\hline Louisiana & $X$ & $X$ & $\mathrm{X}$ & $\mathrm{X}$ \\
\hline Missouri & $X$ & & & \\
\hline Montana & $\mathrm{X}$ & & & \\
\hline Ohio* $^{*}$ & & & & $\mathrm{X}$ \\
\hline Washington & & $\mathrm{X}$ & $\mathrm{X}$ & \\
\hline \multicolumn{5}{|c|}{$\begin{array}{l}\text { Sources: State legislation as cited in the reference section, including Hawaii Legislature } \\
\text { 2006b, lowa 2006, Louisiana 2006, Minnesota 2005, Missouri 2006, Ohio 2006, RFA } \\
2005 \text { b, and Washington } 2006 \\
\text { *Applies to state vehicles only }\end{array}$} \\
\hline
\end{tabular}

The drivers for the development of RFS legislation are broad, and refinement of these may impact future development of policies. The data supporting the claim of air quality improvements of renewable fuels, for example, is extremely limited. It appears that at low concentrations - such as those incorporated in most current and proposed policies - tailpipe emissions of carbon monoxide, particulates, and most air toxic emissions will decrease, as will

\footnotetext{
${ }^{3}$ Drivers reviewed here are those listed in the published legislation. Other, nonpublished drivers may exist for RFS development, but those are not reviewed in this report.
} 
life-cycle emissions of carbon dioxide. At the same time, tailpipe emissions of nitrogen oxide appear to tend to remain the same or increase, and the evaporative emissions of non-methane hydrocarbons (a precursor to ozone), appear to increase (MO TAP 2006). Before any final determinations are made about air quality impacts, substantial additional testing and research are needed.

In preparation for more research, several policies include triggers that expand the program if higher percentages of ethanol in gasoline or biodiesel are certified at a later date to have no adverse air quality impacts (Table 5, California 2006a, Washington 2006). Tennessee's proposed state vehicle rules present an alternative option to direct renewable fuel market development. That policy, for the purpose of ensuring no negative impacts on air quality, allows the goals for petroleum-based gasoline and diesel to be met by other technologies such as more efficient vehicles and hybrid-electric vehicles.

\begin{tabular}{|l|l|}
\hline Table 5. State Provisions Requiring Air Quality Impacts \\
\hline State & Provision \\
\hline California* & State must certify that there are no adverse air quality impacts \\
\hline Washington & $\begin{array}{l}\text { 2\% requirement initially, but increases to 10\% if state officials } \\
\text { determine that the blend will not have an adverse effect on air } \\
\text { quality }\end{array}$ \\
\hline *Based on proposed legislation \\
\hline
\end{tabular}

\section{Stakeholder Participation}

Based on the potential scale and complexity of building the market for renewable fuels, states have leaned toward inclusion of all interested stakeholders in the policy development process. Similar to most public policy development, as more RFS policies are developed, the stakeholders with interest in participating in the process will streamline. However, the current trend for states is to include a large stakeholder group to incorporate the needs of a wide variety of interested parties and establish broad acceptance of the policy. Stakeholders included in the RFS design process have included representatives from:

- State Department of Transportation

- State Department of Energy (State Energy Office)

- State Department of Agriculture

- State Department of Environment

- State Department of Economic Development

- State Regional Planning Agencies

- Consumer Protection Groups

- Agriculture Groups

- Corn Growing Trade Associations

- State Public Utility Commissions

- Vehicle Manufacturers

- Consumers

- Gas Station Owners

- Petroleum Marketers 
Because of the variety of players, the primary groups participating in the development of each state RFS have been the champions for such a policy in the state. In Washington, for example, the Department of Community, Trade and Economic Development was involved in the development of the RFS because they think it could be a key driver for rural economic development. Determining the specific market players for each of the states is critical to the successful development and implementation of this cross-sector policy.

\section{Market Applicability}

The potential market to which the RFS applies can be defined by the fuel targeted for replacement with renewable energy, the specific fleets to which the requirement applies, and whether there are any thresholds that must be met before the policy is triggered. To date, statebased RFS policies have defined specific market boundaries for the fuels and vehicles to which they apply. Table 6 shows that the market boundaries can include the type of fuel, the grade of fuel, and the specific fleets to which the RFS applies. For example, most states have (or have proposed) an ethanol and/or biodiesel requirement that applies to the total sales by volume of gasoline (for ethanol) or diesel fuel (for biodiesel) in the state. Alternatively, Missouri and Montana focus their efforts on all non-premium motor gasoline sales, but still require that the replacing fuel is ethanol. Finally, Georgia, Ohio, and Tennessee limit the market of their RFS by focusing proposed policies on gasoline consumed by state-owned vehicles. Because some of these policies are still in the development stages, it is challenging to determine whether these market-based differences impact the ability of the state to meet their goals, given the limited scope of the policy.

\begin{tabular}{|c|c|c|}
\hline $\begin{array}{l}\text { RFS applies to motor } \\
\text { gasoline and/or biodiesel all } \\
\text { sales }\end{array}$ & $\begin{array}{l}\text { RFS applies to all non- } \\
\text { premium motor gasoline sales }\end{array}$ & $\begin{array}{l}\text { RFS applies only to state } \\
\text { vehicle fuel use }\end{array}$ \\
\hline $\begin{array}{ll}\text { California* } & \text { Michigan } \\
\text { Colorado } & \text { Minnesota } \\
\text { Delaware* } & \text { Nebraska* } \\
\text { Georgia* } & \text { New Mexico* } \\
\text { Hawaii } & \text { Ohio* } \\
\text { Idaho* } & \text { Oregon } \\
\text { Illinois* } & \text { Tennessee* } \\
\text { Indiana } & \text { Washington } \\
\text { lowa } & \text { Wisconsin* } \\
\text { Kansas* } & \\
\text { Louisiana } & \end{array}$ & $\begin{array}{l}\text { Missouri } \\
\text { Montana }\end{array}$ & $\begin{array}{l}\text { Colorado } \\
\text { Georgia* } \\
\text { Maryland } \\
\text { Ohio } \\
\text { Tennessee* }\end{array}$ \\
\hline
\end{tabular}

Several RFS policies enacted and proposed have included another market-based trend - they included a market trigger after which policy compliance must occur. This trigger is typically structured to be met once in-state supply production reaches a certain threshold. This type of provision was enacted in two states' RFS legislation: Louisiana [2015 or six months after in-state production reaches 50 million gallons per year (mgy) ethanol and 10 mgy biodiesel] and Montana (three months after in-state production of ethanol reached $40 \mathrm{mgy}$ ). This type of policy trigger is designed to promote supply availability, so that supply will be available to meet demand. While neither policy explicitly states that the RFS sales mandate must be met with 
locally produced fuels, there could be the potential for constitutional risks if they (or any other state) decides to implement the standard requiring in-state fuel (through guidance or regulations). ${ }^{4}$

\section{Policy Flexibility}

A primary potential benefit of market-based policies is that they allow for the flexibility of developing a least-cost market for existing renewable fuels, while encouraging development of new cost-effective fuels and infrastructure. However, the existing policies primarily target only two specific renewable fuel types to meet the RFS: ethanol and biodiesel blends. In other words, they require that ethanol and/or biodiesel be used to displace gasoline or diesel and do not allow other fuels such as methanol, butanol, "renewable diesel," 5 compressed natural gas, hydrogen, or other fuels. The prescription of fuel type places a major limitation on the benefits of marketbased policies - primarily the ability of the market to determine the least-cost fuel to meet the policy goal as well as promote innovation of new fuels.

The benefit to limiting the policies to specific renewable fuel types is that it minimizes uncertainty in meeting the goal. However, the limitation reduces the incentives for continued development of other innovative and cost-effective renewable fuels technologies. Without direct market competition among renewable fuels, there is no certainty that ethanol and biodiesel are the most efficient fuels for meeting the goals of increased national security and economic development, as well as decreasing the environmental impact of transportation fuels, the stated primary drivers of state level RFS policies. Further, limiting the types of fuels able to fulfill the requirement has the potential to stifle innovation in the development of new renewable fuels to meet the goals of the government. Some states have recognized this challenge and allowed for other alternative or renewable fuels to meet the goals of the RFS. The Louisiana statute, for example, allows for other alternative fuels ${ }^{6}$ to meet the fuel requirement (Louisiana 2006); and the proposed rules for state vehicles in Tennessee allow for expansion of fuel types to meet the requirement (Tennessee 2006a), possibly indicating a trend toward increased policy flexibility.

In addition to specific fuel-type requirements, most of the enacted RFS policies explicitly require volumetric substitutions of gasoline or diesel across the entire market. Most require that all gasoline sold into the market contain a certain percentage of ethanol (e.g., $2 \%$ or $10 \%$, typically) and/or that diesel fuel sold must contain a certain percentage of biodiesel (e.g., $2 \%$ typically). There are two exceptions to these rigid volumetric requirements. First, the Iowa RFS requires the equivalent amount of $25 \%$ of in-state gasoline sales will be replaced with either ethanol (either E85 or E10) or biodiesel (minimum of B1). Despite limited fuel choices, the policy offers some flexibility rather than dictating the state's fuel mix, allowing producers and distributors to decide how to best meet the policy. This flexibility provides the market with the ability to decide: (1) which fuel works best, based on market conditions (feedstock prices, availability, performance,

\footnotetext{
${ }^{4}$ According to the "dormant commerce clause" of the U.S. Constitution, no state can favor an in-state commodity over an out-of-state equivalent. Specifically, "The U.S. Supreme Court consistently strikes down as unconstitutional [programs] involving interstate goods taxed by states so as to provide local subsidy" (Ferry 2006). Therefore, if any RFS provisions limit eligibility to ethanol and biodiesel produced in-state, they could be overturned if successfully challenged in court.

${ }^{5}$ Renewable Diesel has been distinguished from "biodiesel" both chemically and by process. For example, See www.petrobras.com..

${ }^{6}$ As defined by EPAct 2005.
} 
economics, etc.); (2) whether to sell higher concentrates of ethanol (E85) or biodiesel (B20 or B100) to a smaller percentage of their customers to meet the requirement; and/or (3) whether producers decide to sell the required amount of renewable fuel primarily outside of the coldest winter months, when there are less concerns for fuel quality. ${ }^{7}$

The second exception is a minor adjustment: Washington State requires that an equivalent of $2 \%$ of diesel sales be replaced with biodiesel, rather than require that all diesel contain $2 \%$ biodiesel (B2). The reasoning is based on Minnesota's experience of some B2 fuel-quality challenges in the winter (Green Car Congress 2006), which were mostly corrected by tightening quality standards and strengthening enforcement penalties on out-of-specification biodiesel. However, an unanticipated result is that Washington incorporated some flexibility as to how the state meets the requirement, though to a lesser degree than Iowa. Producers will be able to: (1) sell higher percentages of biofuels (e.g., B20, B100) to a smaller group of customers, and/or (2) decide what time of year they sell the renewable fuel.

\section{Binding Targets and Compliance}

Most currently enrolled RFS policies do not have detailed enforcement provisions included in their legislation and assign the development of regulations regarding compliance to a state agency. Because most policies were passed in the past year, regulations are not currently available, so it is difficult to estimate the extent to which enforcement will be included. Iowa offers relatively more detail within the legislation by allowing the state to initiate an "alternate civil enforcement action...for at least one hundred dollars but not more than one thousand dollars for each violation. Each day that a continuing violation occurs shall be considered a separate offense. If a party... fails to pay...the penalty... within thirty days...the state may initiate a criminal prosecution." (Iowa 2006). Legislative direction regarding the repercussions of noncompliance to the agency responsible for developing regulations is a representation of active state support for the development of a market for renewable fuels.

These compliance (and noncompliance) mechanisms send signals to market stakeholders regarding the importance of meeting the state obligations and goals. There is evidence within existing policies that enforcement of binding targets is critical to meeting program goals. For example, the longest running RFS - Hawaii's 1994 law - did not contribute to the development of an ethanol market (the policy goal) until an enforcement policy was enacted when the legislation was amended in 2004 (Hawaii Revised Statutes 2006). Based on the Hawaii experience, as well as lessons learned by renewable portfolio standard policies (see section below), an enforceable policy is critical to the policy meeting its goals.

Another trend associated with binding targets and compliance mechanisms is deciding which sectors of the value chain are burdened with compliance. Within currently enrolled policies, the trend is toward placing that burden on retail outlets for motor fuel. This is an important issue to monitor in policy development, because regulating individual retailers to ensure compliance may be both costly and logistically challenging.

\footnotetext{
${ }^{7}$ Note that emissions considerations may preclude selling high percentages of renewable fuels during the summer in metropolitan areas that are in nonattainment for ozone, if the fuel would lead to an increase in ozone precursors.
} 


\section{Mandate Setting}

As discussed earlier, most enrolled RFS policies target the gasoline and/or diesel fuel market by designating a specific percentage of fuel that must be substituted using ethanol or biodiesel. In addition to limiting the market to prescribed fuel types - and, therefore, limiting its impact on building a market for least-cost renewable fuels, as discussed above - this dominant policy design appears to apply an initial requirement based on the level of replacement fuel that policymakers think can be achieved. The design, however, does not appear to be based on exhaustive research or analysis that examines the actual ability of the market to meet the requirement, nor the potential that the policy will meet the policymaker's main drivers.

States currently considering new RFS standards could integrate analysis within the policybuilding framework to determine the best policy for the specific state. To estimate the appropriate percentage of renewable fuel to which a statewide fuel portfolio could apply, the following analyses could be performed:

- Determining the availability of alternative fuel;

- Researching the potential for market penetration of alternative fuels by assessing market conditions (number of alternative fuel vehicles, location of alternative fuel stations, willingness of farming community to provide feedstock, etc.);

- Calculating the potential impacts of the policy (e.g., air quality, oil offset, economic); and

- Interaction of the mandate/goal with other policies and programs (e.g. federal RFS, nearby state RFS, infrastructure building programs).

In the absence of extensive analysis and research, the policymakers are challenged and they set goals for these first renewable fuels standards. Two possible solutions exist for this challenge. The first is for the state to invest in a greater understanding of the balance of supply and demand for renewable fuels, and structure policies in reaction to the potential availability of and maximum demand for renewable fuels. This analytic investment will pay dividends through a thorough understanding of the market and potential for fuels, as well as provide better input into the policy and, ideally, easier implementation as a result of understanding the market. The drawback, however, is that analytic studies of this magnitude can be costly and time consuming, and policy momentum, as well as politics, may preclude these as an option. The second solution is to set an easily achievable goal at the start and create a flexible target within the policy allowing for incremental increases as the market reaches the goal. This allows for the target to be adjusted upward, based on the implementation experience as well as changes in the global market. The drawback of this solution, however, is that the initial target may be set so low that it does not increase investment in biofuels as quickly as intended.

Another aspect of standard mandate setting is clarity of the standard. That is, the goal of the policy and the mechanisms for meeting it must be clear. Whether the policy indicates that the standard must be set on a volumetric or total sales basis, or whether it applies only to a certain type of fuel or market segment, are important points of clarification that ease confusion for the implementing parties. 


\section{Fuel-Quality Standard Setting}

Another important aspect of creating a stable market for renewable fuels within a state is ensuring that national-level fuel suppliers and vehicle manufacturers are working with a single type of fuel when producing their product. While state-level RFS policies are designed to promote renewable fuel use within a state, producers and vehicle manufacturers work on a much larger scale. A uniform quality standard for the makeup of renewable fuels is critical to these stakeholders for cost minimization and general market support.

Current trends in state RFS development show that most states are working with national-level standards, with a preference to those quality standards issued by the U.S. EPA (Table 7). The federal renewable fuels standard requires the EPA to promulgate regulations on fuel-quality standards for ethanol and biodiesel (EPAct 2005), and that is in progress. In the meantime, many states are relying on the American Society for Testing and Materials (ASTM) standards for fuel quality, where applicable. Maintaining this trend toward uniform standards may prove to be a challenge if the federal quality standards are delayed beyond state implementation dates for ethanol or biodiesel, or if other fuels without uniform federal standards come into development.

\begin{tabular}{|c|c|c|c|}
\hline State (yr) & Requirement & By & Fuel Quality Standards \\
\hline $\mathrm{HI}(1994)^{*}$ & $10 \%$ ethanol (E10) & 2008 & ASTM or USEPA when available \\
\hline IA (2006) & $\begin{array}{l}25 \% \text { biofuels } \\
\text { equiv. }{ }^{* *}\end{array}$ & 2020 & ASTM \\
\hline LA (2006) & $\begin{array}{l}2 \% \text { ethanol (E2) } \\
2 \% \text { biodiesel (B2) }\end{array}$ & $2015^{* * *}$ & $\begin{array}{l}\text { Ethanol: ASTM D4806 } \\
\text { Biodiesel: USEPA }\end{array}$ \\
\hline $\mathrm{MN}(1991)^{*}$ & $20 \%$ ethanol (E20) & 2013 & $\begin{array}{l}\text { USEPA or ASTM Standard written into } \\
\text { legislation }\end{array}$ \\
\hline MO (2006) & $10 \%$ ethanol (E10) & 2008 & ASTM \\
\hline WA (2006) & $\begin{array}{l}2 \% \text { ethanol }(\mathrm{E} 2) \\
\text { Equiv. of } 2 \% \text { diesel }\end{array}$ & 2008 & ASTM or EPA when Available \\
\hline
\end{tabular}

\section{Cost Caps}

A select number of states have incorporated caps that negate the policy if the costs to the consumer (or other market) is considered to be a burden. In Louisiana, the statute requires that the price of wholesale Louisiana-manufactured ethanol be equal to or less than an average gallon of regular unleaded gasoline sold in the state for 60 days before the alternative fuel requirement goes into effect (Louisiana 2006). The Colorado state vehicle rule includes a similar provision that only requires the use of biodiesel if the price is no greater than 10 cents more than regular diesel (Colorado 2006). 


\section{Summary of Current State Policy Trends}

The current policy environment for state-level RFS policies is developing rapidly, with 10 states enacting policies and 17 more proposing or taking other actions. The major drivers for these policies, according to legislation, are to improve the economy and the environment (health and air quality, primarily), and increase dependence on local fuel sources.

This review shows that although these drivers have led, in most cases, to wide-ranging stakeholder involvement in the policy development process and met the immediate needs of the drivers, current policies are still limited in terms of satisfying the drivers in the long term. Specifically, the policies are limited by a lack of flexibility to meet the goals with least-cost options. Further, most current policies also lack stringent enforcement provisions, a critical piece of effective binding targets. The remainder of this paper reviews selected national-level RFS policies, as well as use of a similar policy mechanism in the electric sector. These experiences can inform revisions in current RFS policies, and contribute to development of future RFS policies that meet the needs of the state in the long term. The final section draws conclusions from the collected experience with renewable fuels standards and initial best practices.

\section{Lessons to Inform State Policy: National and International RFS Policies}

Multiple RFS-type policies, called "obligations," are being implemented internationally and nationally in the United States. Table 8 presents a selection of these policies, and the remainder of this section identifies and describes the attributes of these policies that can inform RFS policy development at the state level. 


\begin{tabular}{|c|c|c|}
\hline Country - Policy & Brief Description & Date Approved \\
\hline European Union ${ }^{8}$ - Biofuels Directive & $\begin{array}{l}\text { Sets target for EU-wide biofuel use of } 2 \% \text { by December } 2005 \text { and } 5.75 \% \text { by } \\
\text { December } 2010 \text {, and calls on member states to do the same. }\end{array}$ & 2003 \\
\hline Canada $^{9}$ - Provincial Mandates & Ontario has committed to $5 \%$ ethanol in fuels by January $1,2007$. & 2004 \\
\hline $\begin{array}{l}\text { Czech Republic }{ }^{10} \text { - Comprehensive } \\
\text { Energy Policy }\end{array}$ & $\begin{array}{l}\text { Requires that } 15-16 \% \text { of total energy consumption is from renewable energy } \\
\text { by } 2030 \text {. Provides financial incentives to that end. }\end{array}$ & 2004 \\
\hline $\begin{array}{l}\text { Hungary }{ }^{11} \text { - Government resolution } \\
\text { on the use of biofuels }\end{array}$ & $\begin{array}{l}\text { A target to increase biofuels in transport to } 0.4-0.6 \% \text { by } 2005 \text { (from } 0.0 \% \text { ). This } \\
\text { proportion should reach } 2 \% \text { by } 2010 \text {. }\end{array}$ & 2004 \\
\hline Australia $^{12}$ - Biofuels Action Plan & $\begin{array}{l}\text { The industry/government partnership target of } 350 \text { megalitres of biofuels by } \\
2010 \text {. }\end{array}$ & 2005 \\
\hline $\begin{array}{l}\text { Spain - Renewable Energy Plan for } \\
2005 \text { - } 2010\end{array}$ & $\begin{array}{l}\text { Spain's new national energy plan is designed to promote the use of renewable } \\
\text { energy sources in Spain and reduce the emission of greenhouse gases. The } \\
\text { Spanish government's focus on renewable energy sources is intended to } \\
\text { reduce Spain's dependence on oil imports, furthering their efforts to fulfilling } \\
\text { the Kyoto Protocol and reducing use of nuclear energy. } \\
\text { By } 2010 \text {, Spain expects } 12.1 \% \text { of Spain's overall energy needs and } 30.3 \% \text { of } \\
\text { total electricity consumption to be met by renewable energy sources. The } \\
\text { Spanish government has raised its target for the production of bioethanol and } \\
\text { biodiesel to } 2.2 \text { million tonnes of oil equivalent (toe) in } 2010 \text { from an initial } 0.5 \\
\text { million toe. The energy industry is expected to finance } 77 \% \text { of the overall cost } \\
\text { of the renewable energy plan, and other private sector industries another } 20 \% \\
\text { and the government, the remainder. Tax incentives will also be offered. }\end{array}$ & 2005 \\
\hline $\begin{array}{l}\text { United States }^{13} \text { - National } \\
\text { Renewable Fuels Standards (EPAct } \\
\text { 2005) }\end{array}$ & $\begin{array}{l}\text { Part of the } 2005 \text { revisions to the Energy Policy Act (EPAct) was an RFS } \\
\text { requiring } 4.0 \text { billion gallons (approx. } 2.78 \text { volume percent of gasoline) sold or } \\
\text { introduced into commerce in the continental U.S. be renewable fuel starting in } \\
2006 \text {, increasing to } 7.5 \text { billion gallons by } 2012 \text {. }\end{array}$ & 2005 \\
\hline
\end{tabular}

${ }_{9}^{8}$ http://www.environmental-finance.com/2006/0602feb/biofuel.htm

9 Australian Government Biofuels Task Force. 2005. Report of the Australian Government Biofuels Task Force to the Prime Minister. URL:

http://www.dpmc.gov.au/biofuels/report/report full.pdf

${ }^{10}$ IEA 2006. [IEA] International Energy Agency. Johannesburg Renewable Energy Coalition Policy Database. URL:

http://www.iea.org/textbase/pamsdb/detail.aspx? mode $=\mathrm{jr} \& \mathrm{id}=1570$. Accessed December 2006.

${ }^{11}$ Government resolution 2233/2004. (IX. 22.)

${ }^{12}$ Office of the Prime Minister, Australia. 2005. News release announcing the National Biofuels Target. URL:

http://www.pm.gov.au/news/media_releases/media_Release1734.html 


\begin{tabular}{|l|l|l|}
\hline $\begin{array}{l}\text { United Kingdom } \\
\text { Renewable Transport Fuels } \\
\text { Obligation (RTFO) }\end{array}$ & $\begin{array}{l}\text { In November 2005, the government announced it would introduce a } \\
\text { Renewable Transport Fuel Obligation (RTFO) - a long-term mechanism } \\
\text { requiring transport fuel suppliers to ensure a set percentage of their sales are } \\
\text { from a renewable source. The RTFO will be introduced in 2008-09, with the } \\
\text { obligation level set at 5\% in 2010-11. This will deliver savings of 1 MtC by } \\
2010 .\end{array}$ \\
$\begin{array}{l}\text { Budget } 2006 \text { sets out further details on the RTFO. The level of obligation will } \\
\text { be } 2.5 \% \text { in } 2008-09 \text { and 3.75\% in 2009-10. This will ensure significant growth } \\
\text { of biofuels prior to reaching the } 5 \% \text { level in 2010-11, while recognizing the time } \\
\text { required to build production capacity and develop the necessary infrastructure } \\
\text { to blend and supply the fuels. RTFO levels beyond 2010-11 will be set in due } \\
\text { course, but the government intends that the target should increase beyond } 5 \% \\
\text { after 2010-11, as long as infrastructural requirements and fuel and vehicle } \\
\text { technical standards allow, and subject to the costs being acceptable to the } \\
\text { consumer. }\end{array}$ & 2005 \\
\hline $\begin{array}{l}\text { Notes: } \\
\text { a. Obligation policies in Spain, Hungary, France, Austria, Slovenia, and those planned in the UK, Germany, the Czech Republic, and the Netherlands } \\
\text { can be applied to the EU nonbinding directive. } \\
\text { b.Information in this table, while sourced to original country-level data and legislation where possible, can be found in summary form in the } \\
\text { International Energy Agency-hosted Johannesburg Renewable Energy Coalition Database of International Policies Regarding Renewable Energy: } \\
\text { http://www.iea.org/textbase/pamsdb/jrlist.aspx?by=techno }\end{array}$ \\
\hline
\end{tabular}

\footnotetext{
${ }^{13}$ EPAct 2005

${ }^{14}$ UK Department for Transport. 2006. Renewable Transport Fuel Obligation Web site. URL: http://www.dft.gov.uk/stellent/groups/dft_roads/documents/divisionhomepage/610328.hcsp
} 
Although the majority of these RFS policies are too recent to evaluate, there are aspects of the policies and their development that can inform U.S. state RFS policies:

\section{Biofuels as Part of Comprehensive Energy Plan}

In Spain and the United States, the renewable fuel obligation is part of an overarching energy plan for all sectors. In Spain, the plan also includes detailed information on the expectation of financing for the projects, as well as the role of public funding. This type of policy measure may result in greater stakeholder success and a better chance at effective policy implementation, because it presents a holistic view of energy policy and, in some cases, recognizes the importance of supporting new facility financing.

\section{Target Flexibility}

The Spanish plan also explicitly allows for a revision to the initial targets, if needed, as a result of changes in the market, including activities of other countries, fuel prices, and demand. Because of the rapid development of the market for biofuels in the current marketplace, it is challenging for states and countries to project where supply and demand will be in the future. The ability to update goals within a policy (as described in the trends section above) increases program uncertainty to the investment community, and that should be carefully balanced against the costs of initial investment in market analysis and renewable fuel potential.

\section{Fuel Flexibility}

While the Spanish plan and many others are limited to biodiesel and bioethanol, the UK program, scheduled to begin in 2008, allows for any renewable fuel to meet the goal. Both programs can apply results to the EU directive, which also focuses on bioethanol and biodiesel, but it also asks member states to consider options for research and development of alternative biofuels. EU member states have responded to this in different ways, from the UK approach of complete fuel flexibility, to the Hungarian approach to set the target for biofuels for bioethanol and biodiesel, but to create a biofuel program researching alternative fuel sources. ${ }^{15}$ In Australia, the RFS calls for any renewable fuels. In the United States, the RFS is directed toward the ethanol market, with instruction to the implementing agency (Environmental Protection Agency) to include cellulosic ethanol beyond 2012. While this provides incentive for innovation in the ethanol market, it does not provide for the development of a true, market based, renewable fuels standard as it does not promote cross-fuel competition and least cost compliance. Increased flexibility in policy compliance increases the opportunity for economically efficient competition in the renewable fuels market.

\section{Binding Targets}

While many of the countries represented here have established targets and not binding goals, there is evidence of pressure on governments, especially the European Union, to make targets binding. At least twice in 2006, once by Eurofores, a European environmental group and once by

\footnotetext{
${ }^{15}$ Hungarian Government. 2003. Report of the Republic of Hungary to the EU Commission on the Promotion of the Use of Biofuels for Transport. URL: http://www.ebbeu.org/legis/Hungary\%201st\%20report\%20Dir\%202003\%2030_EN.pdf
} 
eBIO, ${ }^{16}$ the European Bioethanol Trade Association, ${ }^{17}$ the EU has been called on to reduce uncertainty in the investment market by making the targets mandatory for member states. While binding targets and penalty provisions have been suggested to be stronger policies, countries with very little or no infrastructure, such as Hungary, suggest in their literature that the targets are a first step for nurturing a new industry in the country. ${ }^{18}$

The U.S. and UK policies include a schedule for gradually increasing the requirement, allowing for the growth of renewable fuel capacity over time. This inclusion in a policy can keep market growth, especially in the presence of major incentives, at a sustainable pace. Also, it allows for certainty in the development of biofuel capacity, as well as contributes to periodic evaluation and revision of the program.

\section{Public/Private Partnerships}

The Australian public/private partnership was established through the 2005 Biofuels Action Plan released by the Prime Minister in 2005 (Australian Government Biofuels Task Force 2005). The partnership includes a multimillion-dollar government investment in a grant program to develop new biofuel production capacity and reduce infrastructure barriers, and strengthen the commitment of the public sector to use E10 in all fleet vehicles. Further, the government has agreed to revise fuel specifications to promote research and development into other biofuels. The private sector, in response, has offered public support of ethanol and simplified labeling procedures to better educate and inform consumers. While limiting in the majority of its scope to already developed fuels, the inclusion of a public/private partnership to promote and study renewable fuels presents a model that has the potential for longer-term impact on the market, as a result of increased stakeholder networking and buy-in to the policy. A precursor to this explicit public/private partnership may exist in many of the EU directive-related policies, especially those that include not only a target but also a program to support research, development, and/or deployment (including infrastructure) of biofuels.

\section{Summary of National and International RFS Lessons}

In summary, this selection of federal-level policies shows that, despite the differing scale of the policies, the challenges remain similar. Nationally and internationally, solutions to the challenges related to fuel flexibility and the creation of binding targets and penalty provisions are just now being developed. Innovative policy structures, such as Australia's pairing of a requirement with a public/private partnership in which all parties have a vested interest, may be highly effective. Time and further development of policies will determine what policy structures are the most effective. In the meantime, U.S. states can benefit from understanding the evolution of these policies and the international market for biofuels, and build on the process already begun at that level. This is especially true for those policies that promote innovation in the market through the

\footnotetext{
${ }^{16}$ Environmental Finance. 2006. Planting Seeds on the Forecourt.

URL: http://www.environmental-finance.com/2006/0602feb/biofuel.htm

${ }^{17}$ De Miguel, R. 2006. The Outlook for Bioethanol in Europe: Boosting Consumption. Presented at the World Biofuels Conference, May 2006. URL:

http://www.ebio.org/downloads/publications/060509 eBIO WBC Seville 2006 def.pdf

${ }^{18}$ Hungarian Government. 2003. Report of the Republic of Hungary to the EU Commission on the Promotion of the Use of Biofuels for Transport. URL: http://www.ebbeu.org/legis/Hungary $\% 201 \mathrm{st} \% 20$ report $\% 20$ Dir $\% 202003 \% 2030$ EN.pdf
} 
development of expanded alternative fuels, while focusing on bioethanol and biodiesel based on their current availability and understanding.

Further, these international policies illustrate an increasing interest at the international scale in developing the market for renewable fuels. Although outside the scope of this review, the impact of increased renewable fuels worldwide may also have an impact on the development of the market for renewable fuels within the United States. Finally, it is important to note that in international policy, renewable fuels standards are not the only policy choice for encouraging the market for renewable fuels. Ranging from innovative financing support to direct tax incentives and education programs, international governments are using many mechanisms, another possible lesson for U.S. states.

\section{Lessons to Inform State Policy: International and State Renewable Portfolio Standards (RPS)}

The propagation of state-level renewable portfolio standards (RPS) across the United States has resulted in an increase of more than $4,000 \mathrm{MW}$ of renewable energy capacity to date (UCS 2006a, EIA AEO 2006). Internationally, these policies are also increasing in popularity (von der Linden et al. 2005). RPS policies use the same mandate or obligation system as renewable fuels standards, in that they set targets for renewable energy within a sector and allow the market to develop the least-cost means to that end. The connection to renewable energy markets, as well as the similarity of mechanism, allows policymakers to take lessons learned from RPS development and incorporate them into RFS development. This section presents an overview of the most overarching lessons and how they might be applied to RFS policies.

\section{Binding Targets}

The RPS experience illustrates that the existence of a policy promoting renewable energy will not automatically result in an increase in market share. Several states with RPS policies that either have nonbinding (voluntary) targets or lack enforcement of those targets are not seeing the development of new renewable electricity generation for a variety of reasons. For example, states with an enforceable penalty provision (e.g., Texas and New Jersey) have the most policy compliance (and therefore market development) than states without enforceable requirements (e.g., Nevada).

\section{State-Supported Backing/Long-Term Financing}

RPS policies that do not offer some assurance of cash flow for new plants are not consistently meeting their goals. Such assurance can be in the form of long-term contract requirements or state-supported backing. A robust spot market can also bolster investor confidence if policies are in place to ensure market access for new plants, if renewable generators can have nondiscriminatory access to the wholesale electricity market, and if the RPS encompasses a large market.

\section{Tradable Permits}

In the electricity sector, tradable permits are used to make the attributes of electricity a commodity and also to measure and verify renewable generation. Both of these impacts of tradable permits increase market flexibility, where entities that build eligible projects can sell the attributes from electricity generated to entities with RPS compliance requirements. The 
ownership of RECs is tracked through a central tracking mechanism that ensures that only one entity claims title to the REC and therefore prevents any double-counting. This also allows for regulators to receive reports from the central tracking mechanism that ensures that only one entity owns title to each REC at a time, a design that prevents multiple claims to the same attributes, or double-counting.

Because fuel is a commodity that can be stored and transported, it does not require the creation of a tradable permit to make the market work. However, there are still several benefits of a tradable permit system for RFS. The first is that this system could identify and track the creation of renewable fuels and provide a mechanism for regulators to ensure that no gallon is doublecounted. In addition, by allowing the permits to be openly traded on the market, the fuel can be sold and created local to the resource, which minimizes cost compared to actually transporting the fuel to the region with the requirement. This allows for nonresource rich areas to meet their RFS market goals (particularly for the U.S. RFS) by purchasing the renewable attributes of the commodity fuels. Similar to the SO2 and NOx emission markets, setting up such a system allows for the cheapest resources to be tapped first.

\section{Cost Caps}

Historically, renewable electricity costs more than conventional generation, leading to the possibility of excessive energy costs for consumers through the implementation of an RPS. Arizona, Hawaii, Minnesota, Montana, New Mexico, and Pennsylvania approached this challenge through allowing load-serving entities to request waivers if renewable electricity is "not economic" or are not available at "reasonable" costs. However, leaving these terms undefined results in increased regulatory and market uncertainty. Another type defines limits to the percentage that customer rates may increase as a result of the RPS (Colorado and New Mexico). It is unclear whether any of these attempts at consumer protection either protect consumers or provide the market certainty leading to the development of new generation. As this principle evolves, some state policies have not set this type of artificial percentage limit, but are instead basing cost caps on a clear understanding of the market. These states complete market cost studies in conjunction with RPS policy development to balance between setting the price cap high enough to allow natural market activity, but low enough to protect consumers from exorbitant costs (NYPSC 2004, Smith et al. 2000, UCS 2006b).

\section{Interaction with Other Policies/Programs}

RPS policies are not the only mechanism for promoting the growth of a renewable electricity market. And, as RPS policies become more common, the interaction of the different policies and programs for promotion has become more important to developing a clear, stable renewable electricity market. For example, voluntary green power programs and consumer renewable energy certificate (REC) purchases have become increasingly popular nationwide, both in and outside of states with an RPS. Significant discussion surrounds whether these voluntary purchases should count toward the mandatory RPS goals. If renewable electricity sold in green pricing programs is counted toward RPS requirements, utilities may have an easier time in (and more resources for) achieving the goals set forth by the mandatory RPS policy. If not, each of the mechanisms would be adding to the amount of renewable electricity generated in the overarching electricity market. Because the outcome determines whether voluntary programs are additional to or are as part of RPS goals, the issue has been termed "additionality." 
State RPS policies have concluded differently on the additionality issue, and that discussion is beyond the scope of this report. However, the themes surrounding these challenges will apply to RFS as the market for renewable fuels grows and as a result of an existing federal requirement. To date, there is no published discussion of the policy decision regarding how or if the existing state-level RFS policies will apply to the national RFS requirements, but the sum of the current supply requirements at the state and federal level (normalized for heat content) are far outstripped by actual biofuels plants currently under construction and expected to be completed in 2009 (RFA 2007, NBB 2006b). Currently, the supply of renewable fuels supply in development is projected to exceed all the current state and federal requirements (RFA 2007, NBB 2006b). However, as the policies develop and expand, this will be a growing issue for policymakers to consider.

\section{Summary of Lessons from International and State RPS}

The overarching lesson from existing international and state-level RPS policies is that clear language concerning the major design and implementation aspects of state requirements has proven critical to their success. Studies of international RPS policies have also found that the determining factor in many RPS policies is the quality of the policy design in terms of stakeholder involvement, binding targets, and penalty provisions (van der Linden et al. 2005). RPS policies meeting their goals have built market share for renewable energy establishing the following:

- Statement of RPS application to specific markets/stakeholders

- Uniform standard to be met, as well as methodologies for compliance calculation

- Deadlines and length of requirement

- Alternate compliance options/penalty provisions

\section{Conclusion: Informing Current and Future State RFS Policies}

Although there are a variety of mechanisms (e.g., tariffs, financial incentives) available to states for promoting renewable fuels markets, state-level RFS policies are growing in popularity, with 10 in effect and 17 more proposed or under consideration. There are many specific lessons to be learned from the current policy climate for state-level RFS, as well as state, national, and international RPS and RFS. This review of RFS policies makes it clear that those that meet their goals are carefully designed and implemented including the setting of binding targets with enforcement provisions and clear compliance mechanisms, strong stakeholder participation, and standards that are well researched and/or flexible to changes in the market. The basic considerations for state-level RFS policies include:

- Clarity of Drivers. Most current state legislative drivers include increased fuel selfsufficiency, improved environment, and local economic benefits through increased renewable fuel use. Well-designed market-based policies are a clear option for meeting these goals.

- Market Applicability. State policymakers must determine the limitations on the market to which the policy applies. Restricting market size (e.g., state fleet vehicles only) allows for a more controlled testing environment for the policy, but also limits the benefits of a broad market action. 
- Educated Standard Setting. Effective goals and mandates for renewable fuels standards should be based on resource availability as well as other market characteristics.

- Fuel Choice Flexibility. One of the greatest benefits of this type of market-based mechanism is that it allows for the lowest-cost fuel to meet a mandate (instead of mandating a specific fuel) while also applying enough certainty that the requirement will be there in the investment community for the development of advanced renewable fuels. Current state-level policies are not reaping the full benefit of this mechanism when only particular fuels (e.g., ethanol, biodiesel) are considered to be renewable fuels.

Further, successful policies in other sectors and at the international level can inform state policy development because they include:

- Policy Flexibility. Experience in the RPS and international RFS arena illustrate that successful market-based policies are flexible, allowing for as much market input as possible. This includes allowing for least-cost renewable fuel options to meet the requirement (not limiting to specific fuel types).

- Binding Targets. State RPS policies illustrate that binding targets paired with clear compliance mechanisms and penalties provide the most investment certainty in a policy, leading to reduced financial risk and increased success of the policy.

- Cost Caps. States policies need to include provisions for consumer protection in cases of extreme fuel prices. Lessons from RPS development (specifically in Massachusetts) indicate that extensive market research is required to appropriately set cost caps that minimize uncertainty in the investment community, and therefore increase the likelihood of successful renewable fuel development.

- Tradable Permits for Measurement and Verification. These tradable credit systems have become the centerpiece facilitating compliance in RPS policies. For state RFS provisions, this could be done through a similar mechanism. EPA is currently investigating a credit trading system as part of the federal RFS, which may aid states in development of such systems.

Other interesting policy developments worth consideration are incorporating into the larger comprehensive plan (e.g., Spain) and supporting a public/private partnership (e.g., Australia). Although these advanced mechanisms have not been evaluated, they may provide an opportunity for further success in meeting drivers.

Overall, activity in development of renewable fuels standards worldwide is evolving at a rapid pace, and lessons from existing and proposed policies as well as those in different sectors can inform the development of new policies. Challenges to policy development include the creation of clear and flexible goals with transparent compliance mechanisms and strong enforcement provisions. In addition, policies with strong stakeholder input and state support illicit buy-in from implementers and are more likely to lead to accomplishing stated goals. In the longer term, policies with fuel flexibility provisions will contribute most to innovation of lowest cost fuels for compliance and long-term meeting of the drivers behind encouraging and building a competitive market for renewable fuels. 


\section{Appendix \\ U.S. States with RFS Policy Action (December 2006)}

As of December 2006, there are 10 states with implemented renewable fuels standard (RFS) policies. Although all the policies attempt to expand the market for ethanol within the state, they have nuanced differences that conform to state needs. This appendix outlines known details of the state policies in effect, those that are proposed, and those states that have expressed interest.

\section{Colorado}

Description of Key Points: All state-owned diesel vehicles and equipment to be fueled with (B20) by January 2007. Policy is negated if B20 is 10 cents more per gallon than the price of conventional diesel (Colorado 2006).

\section{Hawaii}

Drivers. In 1994, the Hawaii State Legislature passed a law requiring that $85 \%$ of gasoline sold in the state contain $10 \%$ ethanol by volume (Martin 2004). The law was an attempt to expand the market for the sugar crops in Hawaii, but was largely ineffective as it lacked regulations and enforcement. Since the passage of the law, the legislature periodically revisits the issue to attempt to revive the legislation. In 2004, the state filed administrative rules implementing the law; and, in 2006, extended the deadline for compliance to 2008 .

Description of Key Points. The original 1994 legislation required that $85 \%$ of Hawaii's gasoline sales by volume be comprised of $10 \%$ ethanol fuel (Hawaii Revised Statutes 1994). In 2002, the law was revised to incorporate implications for noncompliance to be determined by the state; and, in 2004, administrative rules regarding the law were released with a target compliance date of April 2006 (HDBET 2004). Exemptions to the rule occur should the state determine that the requirement presents undue economic burdens on the state. Revised legislation, presented in the 2006 legislative session, extended the compliance date to April 2008 (Hawaii Legislature 2006). The revised legislation also directs state vehicles to use alternative fuels and ethanol whenever possible (Hawaii 2006).

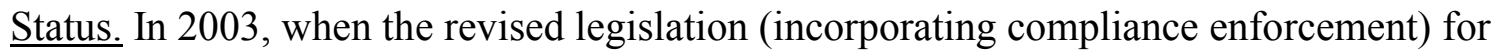
the $10 \%$ mandate was proposed, the Hawaii Department of Business, Economic Development, and Tourism (HDBET) conducted a study of the economic feasibility of the policy. The study found that because of the increased infrastructure improvements necessary in Hawaii to meet the mandate, the economic benefits could also be met by changing the rule that the state could only sell the ethanol in-state.. The report recommended that the ethanol producers be allowed to export ethanol instead of using it immediately to meet the fuel requirement in Hawaii (Gieskes and Hacket 2003) and started a discussion surrounding the rule. In 2006, however, the timeline for compliance was extended to 2008 , but the rule remained unchanged in terms of the requirement. 


\section{Iowa}

Drivers. The Iowa Corn Growers Association was a proponent of a more stringent 25\% by 2015 goal, indicating pressure on the state legislature for a stringent law from state corn growers. Another strong player in the passage of the legislation is the Iowa Renewable Fuels Association, a trade association made up of Iowa-based ethanol and biodiesel producers.

Description of Key Points. The act requires that biofuels replace $25 \%$ percent of all gasoline sales by January 1, 2020. The legislation defines biofuels as ethanol or biodiesel, and allows for flexibility between the two for meeting the requirement. The law requires that the fuel be agriculturally based, but not that it is produced with Iowa crops. The requirement is scheduled to take effect beginning in 2009, according to the schedule in Table A-1. To assist retailers in meeting the goal, a tiered retailer income tax incentive of six and one-half cents per gallon of biofuels for those in compliance with the RFS takes effect in 2009.

\begin{tabular}{|l|c|}
\hline \multicolumn{2}{|l|}{$\begin{array}{l}\text { Table A-1. Compliance Schedule } \\
\text { for lowa RFS }\end{array}$} \\
\hline Year & $\begin{array}{l}\text { Percentage of } \\
\text { Gasoline Sales } \\
\text { Bio-fuel Required }\end{array}$ \\
\hline 2009 & $10 \%$ \\
\hline 2010 & $11 \%$ \\
\hline 2011 & $12 \%$ \\
\hline 2012 & $13 \%$ \\
\hline 2013 & $14 \%$ \\
\hline 2014 & $15 \%$ \\
\hline 2015 & $17 \%$ \\
\hline 2016 & $19 \%$ \\
\hline 2017 & $21 \%$ \\
\hline 2018 & $23 \%$ \\
\hline 2019 & $25 \%$ \\
\hline $\begin{array}{l}\text { Note: } \text { For retailers with <200,000 } \\
\text { gallon annual sales, compliance } \\
\text { targets are delayed two years } \\
\text { Source: IOWA RFA 2006 }\end{array}$ \\
\hline
\end{tabular}

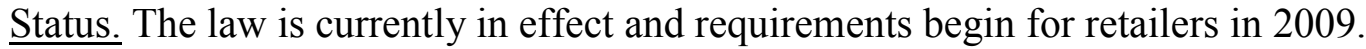

\section{Louisiana}

Drivers. Louisiana's primary driver for RFS implementation was to create a market for ethanol and biodiesel production within the state. One of the primary goals of the legislation was to propel Louisiana into a leadership position in renewable fuels among southern states (Odum 2006). The legislation states that incorporating the use of renewable fuels is a matter of public policy because it is expected to:

1) Expand fuel availability without increasing dependence on foreign oil,

2) Reduce consumer fuel process,

3) Spur Louisiana's rural economy (through increased production and building plants and distribution centers for fuel within the state), and 
4) Improve the state's environment through the use of clean-burning renewable fuels (Louisiana 2006).

Description of Key Points. The Louisiana state RFS calls for $2 \%$ of gasoline sold in the state to be ethanol. Because Louisiana's RFS is driven by increasing the market for production in the state, the $2 \%$ ethanol in gasoline requirement only goes into effect within six months after more than 50 million gallons of ethanol per year are produced within the state. Similarly, the biodiesel requirement goes into effect when the production of biodiesel within the state reaches 10 million gallons annually. Aviation fuels are exempt from the state rules.

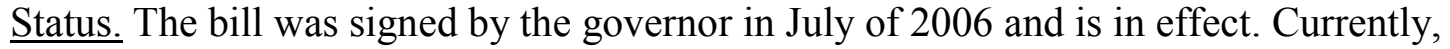
only one biodiesel facility is operational in Louisiana, with plans for more (Biodiesel Magazine 2006). The RFS will take effect six months after production reaches 50 million barrels of ethanol and 10 million barrels of biodiesel annually.

\section{Maryland}

Description of Key Points. By 2008, half the state fleet normally powered by diesel must be using a blend of at least B5 (NBBa 2006).

\section{Minnesota}

Description of Key Points. The Minnesota statute, passed in 2005, requires that 20\% of all gasoline sold by volume must be ethanol by 2013 (Minnesota 2005).

Status. The $20 \%$ ethanol goal is an extension of the previous $10 \%$ ethanol standard of 1991. The original 1991 law spurred the infrastructure needed to meet the new goal (Apollo 2006).

\section{Missouri}

Drivers. Creating a market for and expanding the corn market in Missouri is the primary driver for the Missouri RFS.

Description of Key Points. The Missouri law, signed July 5, 2006, requires that all nonpremium motor gasoline sold in Missouri contain 10\% ethanol by volume by 2008 . Eighty percent of the feedstock used to meet the requirement must be produced in Missouri or in plants more than half-owned by Missouri residents. The statute also authorized a grant program to subsidize Missouri ethanol producers to assist in building the market.

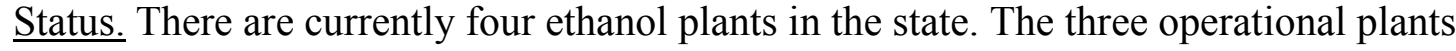
produce more than 100 million gallons of ethanol annually (Blunt 2006). 


\section{Montana}

Description of Key Points. Three months after the state is shown to produce the equivalent of 40 million gallons per year of ethanol, all non-premium gasoline in the state is required to contain $10 \%$ ethanol. In order to spur supply, the legislation also enacted a production incentive of $\$ 2$ million per plant per year within the state (RFA 2005b).

\section{Washington}

Drivers. The legislature determined that a market for renewable fuels was in the public interest of the state of Washington in order to reduce dependence on foreign oil, improve health and quality of life for residents, and stimulate growth of a new industry in agricultural and rural communities (Washington 2006).

Description of Key Points. The statute requires that gasoline sold in the state must contain $2 \%$ ethanol by volume. If higher percentages of ethanol in gasoline are found not to adversely affect air quality by state officials, the requirement can be increased to up to $10 \%$ ethanol by volume. Similarly, diesel fuel distributors are required to certify that $2 \%$ of total diesel sales by volume annually are biodiesel when the director of agriculture determines that the state can supply the need - or by November 30, 2008.

\section{Summary of Proposed RFS Policies (December 2006)}

Most of the information below, including the identification of most pending legislation, came from the Renewable Fuels Association (RFA 2006).

\section{California}

Description of Key RFS Points: The environmental impacts of biodiesel fuel will be studied, and once it is determined that emissions will not be adversely impacted, a renewable diesel standard will come into effect. For all diesel fuel used in an internal combustion engine, the draft legislation (SB 1675) requires that at least $\%$ is biodiesel starting no later than one year after the findings of the aforementioned study are published, and at least $5 \%$ biodiesel no later than two years after the $2 \%$ requirement comes into effect (California 2006a).

Current Status: Passed and re-referred to Appropriations Committee on June 29, 2006. Passed Senate 22-16 on August 31, 2006. Passed Assembly committee August 21, 2006, then failed 33 to 40 on Assembly floor (California 2006b).

\section{Colorado}

Description of Key RFS Points: The draft legislation (SB 138) would require that all gasoline sold in Colorado contain a certain percentage of ethanol by a predetermined date (Table A-2).

Table A-2. Compliance Schedule for Colorado RFS

\begin{tabular}{|c|c|}
\hline Percentage ethanol & By when \\
\hline $5 \%$ & January 1,2007 \\
\hline $10 \%$ & January 1,2009 \\
\hline $15 \%$ & January 1,2011 \\
\hline $20 \%$ & January 1,2013 \\
\hline
\end{tabular}


It also requires that $75 \%$ of all gasoline sold from November to April contain 10\% ethanol.

Current Status: Passed the house and the senate, but was vetoed by then-Governor Bill Owens, who cited that it could increase fuel prices and that Denver already requires $10 \%$ ethanol from November through February (Owens 2006).

\section{Delaware}

Description of Key RFS Points: Draft legislation (SB 132) would require that all diesel fuel sold in the state contain at least 2\% biodiesel, effective January 2007.

Current Status: Assigned to the House Transportation/Land Use and Infrastructure Committee June 29, 2005.

\section{Georgia - State Vehicle Requirement}

Description of Key RFS Points: (1) Draft requirement (SB 453) for state-owned vehicles to purchase at least $2 \%$ biodiesel fuel, as long as the cost does not exceed $105 \%$ of the cost of unblended diesel.

(2) Also draft requirement (HB 1412) for state-owned vehicles to use renewable fuel to replace gasoline or diesel used in motor vehicles or equipment, as long as the fuel is compatible with the vehicle or equipment technology, and is reasonably available at a cost similar to that of conventional fuel.

Current Status: (1) Passed the Senate (February 13, 2006) and is pending in the House. (2) Conference Committee report adopted March 30, 2006.

\section{Idaho}

Description of Key RFS Points: Sixty days after the state certifies in-state annual production of at least 30 million gallons of ethanol per year, all gasoline sales within the state must contain at least $10 \%$ ethanol ( $9.2 \%$ plus denaturant). Exempts premium gasoline used exclusively for aircraft that use motor vehicle fuel (SB 1364).

Current Status: SB 1364 Passed the Senate (February 23, 2006). House Environment, Energy and Technology Committee referred bill to an Interim Energy Study Committee. (March 10, 2006).

\section{Illinois}

Description of Key RFS Points: Draft legislation (SB 2236) would require that 10\% of all motor fuel sold or offered in the state be from denatured ethanol starting in 2008, which would increase to $15 \%$ by 2012 .

Current Status: Passed the Senate (February 28, 2006). Stalled at end of legislative session in the House Rule Committee 


\section{Kansas}

Description of Key RFS Points: Proposed requirement of replacing 10\% of gasoline (minimum of $9.2 \%$ and no more than $10 \%$ ) sold or offered with ethanol and $2 \%$ of diesel sold or offered with biodiesel by January 2010 (SB 387).

Current Status: Died in committee on May 25, 2006 (Kansas 2006).

\section{Michigan (Information provided via Kaplun 2006)}

Description of Key RFS Points: (1) Draft bill requiring 2\% of gasoline sold or offered in the state to be ethanol, starting December 31, 2007 (SB 1341) (Michigan 2006a).

(2) Draft bipartisan bill (SB 331/HB 4235). Within 30 days of the publication that the annual capacity for the production of biodiesel fuel in Michigan is greater than 12 million gallons, diesel fuel sold in the state shall include at least 2\% biodiesel (Michigan 2006b).

Current Status: (1) Referred to the Committee on Technology and Energy (June 28, 2006). (2) HB 4235 - re-referred to the Committee on Agriculture (March 21, 2006) and SB 331 - referred to and stalled in the Committee on Transportation.

\section{Nebraska}

Description of Key RFS Points: Draft legislation (LB 848) that all gasoline offered for sale, sold, or dispensed for use in Nebraska (except premium grade) shall contain a renewable fuel content equal to or greater than $3.5 \%$ by weight. Renewable fuel means fuel made from renewable sources such as ethanol produced from corn, sorghum, and biomass.

Current Status: Indefinitely postponed (April 13, 2006 - Nebraska 2006)

\section{New Mexico}

Description of Key RFS Points: Proposal to require that all gasoline sold to customers for use in motor vehicles shall contain $10 \%$ denatured ethanol by volume, and that all diesel fuel sold to customers for use in motor vehicles shall contain $2 \%$ biodiesel fuel (HB 282). The content requirement shall not apply when (1) the secretary, in consultation with the secretary of Taxation and Revenue and the director of the New Mexico Department of Agriculture, determines that sufficient amounts of denatured ethanol or biodiesel fuel are not available to meet the requirements of this section; or (2) the governor determines by executive order that an emergency or disaster has cause or appears likely to cause a disruption in the price or supply of gasoline or diesel fuel (New Mexico 2006a).

Current Status: “Died in committee.” (as of July 21, 2006 - New Mexico 2006b)

\section{Oregon}

Description of Key RFS Points: Draft House Bill 3481 - once ethanol production in the state reaches at least 90 million gallons on an annualized basis, for at least three months, then a retail dealer, nonretail dealer, or wholesale dealer of gasoline may not sell or offer for sale gasoline unless the gasoline contains at least $10 \%$ ethanol by volume (contains not less than $9.2 \%$ and not more than $10 \%$ by volume). Also, once in-state biodiesel production reaches at least 5 million 
gallons annually, for at least three months, then diesel gasoline sold and offered in the state must contain at least $2 \%$ biodiesel by volume (Oregon 2005a).

Current Status: Stalled in Conference Committee upon adjournment (August 5, 2005) (Oregon 2005b).

\section{Tennessee - State Vehicle Requirement}

Description of Key RFS Points: Proposal for all state-owned vehicle fleets consisting of more than 10 motor vehicles to develop a plan to reduce or displace at least $20 \%$ of current petroleum consumption by January 1, 2010 (SB 3748/HB 3626). Each plan shall initiate implementation by January 1, 2007. Goals may be met by displacing through the use of biodiesel, ethanol, synthetic oils or lubricants, other alternative fuels, the use of hybrid electric vehicles, other fuel-efficient or low emission vehicles, or additional methods... [as approved to reduce] harmful emissions. (Tennessee 2006a)

Current Status: Passed by Senate and referred to the Environment, Conservation, and Tourism Committee March 1, 2006). Also passed by House and assigned to Sub-Committee on Conservation and Environment (March 15, 2006) (Tennessee 2006b). Stalled at end of legislative session.

\section{Wisconsin}

Description of Key RFS Points: Draft legislation (AB 15/SB 15) to require that automotive gasoline contains not less than $9.2 \%$ nor more than $10 \%$ ethanol, no later than July 1, 2006 (Wisconsin 2006).

Current Status: AB15 was indefinitely postponed in the senate (March 6, 2006). SB15 failed to pass pursuant to Senate Joint Resolution 1 (May 11, 2006).

\section{Summary of Other State RFS Activity (December 2006)}

\section{Indiana}

Governor Mitch Daniels signed a bill requiring the Environmental Quality Service Council to study the best way to implement the federal Renewable Fuels Standard of EPAct in Indiana. It will also examine the feasibility of requiring all vehicles sold in Indiana to be either E85 or B20 compatible (RFA 2006). Most likely, RFS implementation would include a requirement for gasoline sold in the state to contain a certain percentage of ethanol and/or for diesel fuel sold in the state to contain biodiesel. (REAccess 2006).

\section{Michigan}

HB 5181/SB 1077 established the Fuels of the Future Commission within the Department of Agriculture to investigate and recommend strategies to the governor and the state legislature about how to promote and encourage the use of alternative fuels. This bill was enacted on July 7 , 2006, and the report will be due one year from enactment (Michigan 2006c). 


\section{North Dakota}

At the end of 2005, the commissioner for agriculture released a Roadmap for Renewable Energy in North Dakota. As part of that proposal, he recommends: making ethanol $10 \%$ of every gallon of gasoline sold in the state by 2008 , increasing to $20 \%$ by 2013 . He also recommends that $5 \%$ of every gallon of diesel sold by 2008 is biodiesel, increasing to $10 \%$ by 2012. (Johnson 2005.)

\section{Oregon}

Governor Ted Kulongoski requested that a team of state agencies work with stakeholders to develop a Renewable Energy Action Plan - the final version of which was released in April 2005. The plan contains a few relevant goals, including (Oregon 2005c):

- By 2010, all diesel sold in Oregon will contain 5\% biodiesel and 20\% by 2025.

- All standard (non-premium) gasoline sold in Oregon will contain 10\% ethanol by 2010.

- Diesel used in all state government fleets will be B20 by 2025.

- Five percent of all gasoline sold in Oregon will be E-85 blend by the year 2015, which will increase to $15 \%$ by 2025 .

\section{South Dakota}

U.S. Representative Stephanie Herseth commissioned a report on the impact of high gas prices on South Dakota families. Its results showed that the price of gasoline increased five times faster than inflation, and that a typical two-car South Dakota family paid \$1,860 more for gasoline in 2006 than in 2001. In a news release, she stated "A meaningful commitment to renewable fuels would be win-win for South Dakota families...our rural economy would benefit through the high-paying jobs created by a vibrant renewable fuels industry throughout the heartland." (Herseth 2006)

\section{Virginia}

Governor Tim Kaine signed Senate Bill 262, which outlines a Virginia Energy Plan. The plan directs the Commonwealth Transportation Board to encourage the use of biodiesel and other alternative fuels, to the extent practicable, in vehicles used to provide public transportation (Virginia 2006). 


\section{References (including appendix)}

[Apollo] The Apollo Alliance. 2006. Renewable Fuel Standards Fact Sheet. http://www.apolloalliance.org/strategy_center/model_legislation/rfs.cfm

Australian Government Biofuels Task Force. 2005. Report of the Australian Government Biofuels Task Force to the Prime Minister. URL: http://www.dpmc.gov.au/biofuels/report/report full.pdf

Berry, J. and M. Jaccard. 2001. The Renewable Portfolio Standard: Design Considerations and Implementation Survey. Energy Policy Volume 29, Issue 4 . Pages 263-277.

Biodiesel Magazine. 2006. Louisiana Biodiesel Facility Heads Toward Full Production. http://www.biodieselmagazine.com/article.jsp?article_id=970

[Blunt] Office of the Governor of Missouri, Matt Blunt. 2006. Press Release: Blunt Enacts 10 Percent Ethanol Standard; State, Consumers Recognize Fuel Benefits. Contact: Jessica Robinson 573751 0290. July 5.

California. 2006a. Full Text of Bill Number SB 1675, as Amended on June 29, 2006. http://www.leginfo.ca.gov/pub/05-06/bill/sen/sb_16511700/sb_1675_bill_20060629_amended_asm.html

California. 2006b. Complete Bill History - Bill Number S.B. No. 1675 - Author Kehoe http://www.leginfo.ca.gov/cgibin/postquery?bill_number $=$ sb $1675 \&$ sess $=P R E V \&$ house $=B \&$ author $=$ kehoe

Colorado. 2006. Colorado Revised Statutes 24-30-1104. Available: http://198.187.128.12/colorado/lpext.dll?f=templates\&fn=fs-main.htm\&2.0

De Miguel, R. 2006. The Outlook for Bioethanol in Europe: Boosting Consumption. Presented at the World Biofuels Conference, May 2006. URL:

http://www.ebio.org/downloads/publications/060509_eBIO_WBC_Seville_2006_def.pdf

[EIA AEO] Energy Information Administration. 2006. Annual Energy Outlook 2006 with projections from 2006-2030. Washington, DC: EIA

Environmental Finance. 2006. Planting Seeds on the Forecourt. URL: http://www.environmental-finance.com/2006/0602feb/biofuel.htm

EPAct 2005 Amendments. "Energy Policy Act, Title XV - Ethanol and Motor Fuels, Subtitle A - General Provisions, Section 1501. Renewable Content of Gasoline" signed by President Bush on August 8, 2005. http://frwebgate.access.gpo.gov/cgibin/getdoc.cgi?dbname=109_cong_public_laws\&docid=f:publ058.109 
[EPA] US Environmental Protection Agency. 2005. "Regulation of Fuels and Fuel Additives: Renewable Fuel Standard Requirements for 2006," 40 CFR, Part 80, Federal Register/ volume 70, No. 250, December 30, pp 77325 - 77336.

Gieskes, T. and Hacket, D. 2003. Hawaii Ethanol Alternatives: Review Draft. Prepared for the Hawaii Department of Business, Economic Development, and Tourism. URL: www.hawaii.gov/dbedt/ert/new-fuel/files/ethanol-stillwater.pdf

Green Car Congress. 2006. "Washington State House Passes Renewable Fuel Standard," Green Car Congress Web site, February 12, 2006 http://www.greencarcongress.com/2006/02/washington_stat.html

Hawaii Revised Statues. 2006. Volume 11, Chapter 486J, Section 10. URL: http://www.capitol.hawaii.gov/hrscurrent/vol11_ch0476$\underline{0490 / \mathrm{hrs} 0486 \mathrm{j} / \mathrm{hrs} \text { 0486j-0010.htm }}$

Hawaii. 2006. Bill Status HB2175 HD2 SD2 CD1 "Relating to Energy" - Hawaii State Legislature http://www.capitol.hawaii.gov/site1/docs/getstatus2.asp?billno=HB2175

Hawaii Legislature. 2006b. House Bill 2611. URL: http://www.capitol.hawaii.gov/sessioncurrent/bills/hb2611 htm

[HDBEDT] Hawaii Department of Buisness, Economic Development and Tourism. 2004. Hawaii Administrative Rules, Title 15, Chapter 35: Ethanol Content in Gasoline. Honolulu, HI: Hawaii DBEDT. URL: www.hawaii.gov/dbedt/main/about/admin$\underline{\text { rules/15-35.pdf }}$

Herseth, S. 2006. "Herseth Releases Report Outlining Effect of High Gas Prices on South Dakota Families, U.S. South Dakota Representative Stephanie Herseth, June 2. http://www.house.gov/herseth/press_060206_gasprices.htm

Hungarian Government. 2003. Report of the Republic of Hungary to the EU Commission on the Promotion of the Use of Biofuels for Transport. URL: $\underline{\text { http: } / / \text { www.ebb- }}$ eu.org/legis/Hungary\%201st\%20report\%20Dir\%202003\%2030_EN.pdf

Iowa. 2006. House File 2754 as enrolled. URL: http://www.legis.state.ia.us/aspx/CoolICE/DisplayBills.htm (type in HF2754)

[IOWA RFA] Iowa Renewable Fuel Association. 2006. Factsheet: Provisions of the Iowa Renewable Fuels Standards. URL: www.iowarfa.org/PDF/Iowa RFS Provisions_2ndVERSION.pdf?PHPSESSID= ba5f441206e1657412cf9972ed9bff66

Johnson, R. 2005. "Renewable Energy in North Dakota: A Roadmap for the Future," Roger Johnson, Agriculture Commissioner. http://www.agdepartment.com/RES/RogersRoadmap1.pdf 
Kansas. 2006. Full History on Bill 387 for Kansas Legislature 2005-2006. http://www.kslegislature.org/legsrv-billtrack/searchBills.do

Kaplun, Alex. 2006. Greenwire reporter. Personal communication, 7/19/06

Louisiana. 2006. State of Louisiana Code. Act No. 313 (as enrolled).

Martin, D. 2004. Oil Industry Seeks Delay for Ethanol Rules. Honolulu Star Bulletin. URL: http://starbulletin.com/2004/08/13/business/story1.html

Michigan. 2006a. Status and text of Senate Bill 1341 (2006), Michigan Legislature http://www.legislature.mi.gov/(yqcp4p55qfmp1dzboa3tuu45)/mileg.aspx?page=getObjec t\&objectName=2006-SB-1341

Michigan. 2006b. Status and text of Senate Bill 331 (2006), Michigan Legislature http://www.legislature.mi.gov/(yqcp4p55qfmp1dzboa3tuu45)/mileg.aspx?page=getObjec t\&objectName $=2005-\mathrm{SB}-0331$

Michigan. 2006c. Text of House Bill 5181 - introduces September 15, 2005. http://www.legislature.mi.gov/documents/2005-2006/billintroduced/House/htm/2005HIB-5181.htm

Minnesota. 2005. SF No. $4,3^{\text {rd }}$ engrossment $-84^{\text {th }}$ Legislative Session 2005-2006).

Missouri. 2006. House Bill Numbers 1270 and 1027 Truly Agreed to and Finally Passed.

[NBB] National Biodiesel Board. 2006a. 2006 Legislative Highlights. Available http://www.biodiesel.org/

[NBB] National Biodiesel Board. 2006b. US Biodiesel Production Capacity. http://www.biodiesel.org/pdf_files/fuelfactsheets/Production_Capacity.pdf

Nebraska. 2006. Legislative Bill 848 Regular Session - Bill Status, Nebraska Legislature, http://www.unicam.state.ne.us/scripts/dbBSInfo.asp?Prefix $=$ LB\&BillNumber=848\&Suffi $\mathrm{x}=\& \operatorname{Session}=$

New Mexico. 2006a. House Bill $282-47^{\text {th }}$ legislature - State of New Mexico - Second Session, 2006 http://legis.state.nm.us/Sessions/06\%20Regular/bills/house/HB0282.html

New Mexico. 2006b. New Mexico Legislature - 2006 Regular Session, Bill Tracker for HB 282 - Renewable Fuels Standards Act.

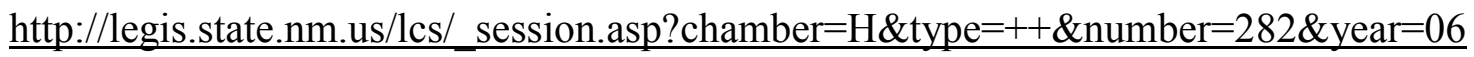

[NYPSC] New York Public Service Commission. 2004. Retail Renewable Portfolio Standard Cost Analysis II, Volume A. Case 03-E-188. Available: http://www.dps.state.ny.us/03e0188_CostStudy_II.htm 
Ohio. 2006. Legislative History of Action taken on Sub. HB 245, $126^{\text {th }}$ General Assembly, http://lsc.state.oh.us/coderev/hou126.nsf/House+Bill+Number/0245?Opendocument and text of latest version of the bill: http://www.legislature.state.oh.us/bills.cfm?ID=126_HB_0245

Oregon. 2005a. House bill 3481 of the $73^{\text {rd }}$ Oregon Legislative Assembly - 2005 Regular Session. http://landru.leg.state.or.us/05reg/measures/hb3300.dir/hb3354.intro.html

Oregon. 2005b. House Bill 3481 - Bill Legislative History, Oregon State Legislature. http://www.leg.state.or.us/cgi-bin/searchMeas.pl

Oregon. 2005c. "Background and Summary: Recent State of Oregon Renewable Energy Initiatives - the Renewable Energy Action Plan," Prepared by the Oregon Department of Energy, final version released April. http://www.oregon.gov/ENERGY/RENEW/docs/REAP-REWG_Summary.pdf

Owens, W. 2006. Letter from Governor Bill Owens to the Colorado Senate, explaining that he vetoes the bill, May 26. http://www.colorado.gov/governor/press/may06/sb138.html

Putsche, V. 2006. E10 Air Quality Impact Summary of Published Literature. Presented to the DOE TAP Webcast on RFS. 2006.

REAccess. 2006. “Alternative Fuel Bill Heads to Governor's Desk in Indiana," Renewable Energy Access, March 14. http://www.renewableenergyaccess.com/rea/news/story?id=44339

[RFA] Renewable Fuels Association. 2007. Bioethanol Production Capacity. URL: http://www.ethanolrfa.org/industry/locations/. Accessed January 15, 2007.

[RFA] Renewable Fuels Association. 2006. "2005-2006 Pending State Renewable Fuels Legislation," Internal document provided directly from the Renewable Fuels Association, Last Updated May 3 (www.ethanolrfa.org).

[RFA]. Renewable Fuels Association. 2005a. Ethanol Report "Minnesota Enacts E20 Requirement," Issue No. 223, May 20. http://www.ethanolrfa.org/objects/documents/392/er223-email.pdf

RFA. 2005b. Ethanol Production Incentives. Accessed through the National Council of State Legislatures (NCSL): http://www.ncsl.org/programs/energy/ethinc.htm

Smith, D, K. Cory, R. Grace, and R. Wiser. 2000. Massachusetts Renewable Portfolio Standard Cost Analysis Report

Tennessee. 2006a. Text of House Bill 3626 and Senate Bill 3748 http://www.legislature.state.tn.us/bills/currentga/BILL/SB3748.pdf 
Tennessee. 2006b. Tennessee General Assembly Bill History Section on Actions Taken on SB3748 and HB3626. http://www.legislature.state.tn.us/bills/currentga/BILL/SB3748.pdf

[UCS] Union of Concerned Scientists. 2006a. RES Policies at Work in the States. Website: http://www.ucsusa.org/clean_energy/clean_energy_policies/res-at-work-in-thestates.html

-----. 2006b. Increase Wisconsin RPS. Website: http://www.ucsusa.org/clean energy/clean energy policies/increase-wisconsin-rps.html)

UK Department for Transport. 2006. Renewable Transport Fuel Obligation Website. URL: http://www.dft.gov.uk/stellent/groups/dft_roads/documents/divisionhomepage/610328.hc $\mathrm{sp}$

Van der Linden, N.H., M.A. Uyterlinde, C. Vrolijk, J. Khan, K. Astrand, K. Erisson, and R. Wiser. Review of International Experience with Renewable Energy Obligation Support Mechanisms. LBNL-57666. URL: http://eetd.lbl.gov/ea/ems/reports/57666.pdf

Virginia. 2006. Summary and status of Senate Bill 262 - Virginia Energy Plan, as enacted with Governor's Recommendations, May 19. http://leg1.state.va.us/cgibin/legp504.exe?061+sum+SB262

Washington. 2006. House Bill 2736 as enrolled.

Wisconsin. 2006. 2005 Assembly Bill 15, 2005-2006 Wisconsin Legislature. http://www.legis.state.wi.us/2005/data/AB-15.pdf 


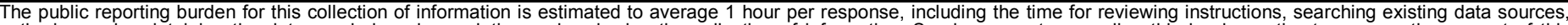

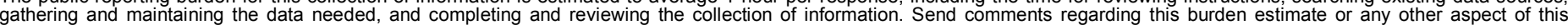

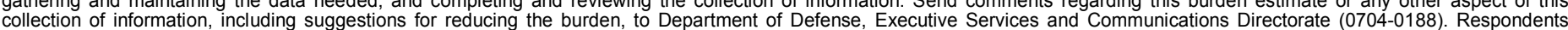

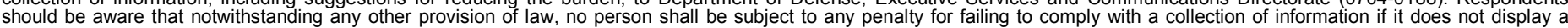

should be aware that notwithstandin

PLEASE DO NOT RETURN YOUR FORM TO THE ABOVE ORGANIZATION.

\begin{tabular}{l|l|l|} 
1. REPORT DATE $(D D-M M-Y Y Y Y)$ & 2. REPORT TYPE & 3. DATES COVERED (FrOm - TO)
\end{tabular} January 2007

Technical Report

4. TITLE AND SUBTITLE

Understanding and Informing the Policy Environment: State-Level

Renewable Fuels Standards

6. AUTHOR(S)

E. Brown, K. Cory, and D. Arent 5a. CONTRACT NUMBER

DE-AC36-99-G010337

5b. GRANT NUMBER

5c. PROGRAM ELEMENT NUMBER

5d. PROJECT NUMBER

NREL/TP-640-41075

5e. TASK NUMBER

6001.5010

5f. WORK UNIT NUMBER

7. PERFORMING ORGANIZATION NAME(S) AND ADDRESS(ES)

National Renewable Energy Laboratory

1617 Cole Blvd.

Golden, CO 80401-3393

9. SPONSORING/MONITORING AGENCY NAME(S) AND ADDRESS(ES)

8. PERFORMING ORGANIZATION REPORT NUMBER

NREL/TP-640-41075

10. SPONSOR/MONITOR'S ACRONYM(S) NREL

11. SPONSORING/MONITORING AGENCY REPORT NUMBER

12. DISTRIBUTION AVAILABILITY STATEMENT

National Technical Information Service

U.S. Department of Commerce

5285 Port Royal Road

Springfield, VA 22161

\section{SUPPLEMENTARY NOTES}

\section{ABSTRACT (Maximum 200 Words)}

Renewable fuels standard (RFS) policies are becoming a popular public policy mechanism for developing the market for renewable fuels in the transportation sector. During the past decade, U.S. states and several countries began implementing these more market-based (less command and control) policies to support increased biofuels production and use. This paper presents an overview of current and proposed U.S. state-level policies, as well as selected electric sector policies and international fuel standard policies. Current U.S. state-level renewable fuel policies list drivers including an improved economy and environment, as well as fuel self-sufficiency. Best practices and experience from an evaluation of renewable portfolio standards (RPS) in the United States and international RFS policies can inform U.S. state-level policy by illustrating the importance of policy flexibility, binding targets, effective cost caps, and tradable permits. Understanding and building on the experiences from these previous policies can improve the policy mechanism and further develop a market for renewable fuels to meet the goals of improved economy, environment, and fuel self-sufficiency.

15. SUBJECT TERMS

Renewable fuels standards; RFS; renewable portfolio standards; RPS; state policy; energy plan; policy drivers; binding targets; markets; cost caps; biofuels; biodiesel; enthanol; international policy; fuels; transportation; Karlynn Cory; Doug Arent; Elizabeth Brown.

\begin{tabular}{|c|c|c|c|c|}
\hline \multicolumn{3}{|c|}{ 16. SECURITY CLASSIFICATION OF: } & \multirow{2}{*}{$\begin{array}{l}\text { 17. LIMITATION } \\
\text { OF ABSTRACT } \\
\text { UL }\end{array}$} & \multirow{2}{*}{$\begin{array}{l}\text { 18. NUMBER } \\
\text { OF PAGES }\end{array}$} \\
\hline $\begin{array}{l}\text { a. REPORT } \\
\text { Unclassified }\end{array}$ & $\begin{array}{l}\text { b. ABSTRACT } \\
\text { Unclassified }\end{array}$ & $\begin{array}{l}\text { c. THIS PAGE } \\
\text { Unclassified }\end{array}$ & & \\
\hline
\end{tabular}

19a. NAME OF RESPONSIBLE PERSON

19b. TELEPHONE NUMBER (Include area code) 